\title{
PERILAKU NELAYAN DALAM LINGKUNGAN KELUARGA TERHADAP PENDIDIKAN ANAK DI DESA TAMALATE KECAMATAN GALESONG UTARA KABUPATEN TAKALAR
}

\author{
Ramli \\ Abd. Rahman Getteng \\ Muliaty Amin \\ Susdiyanto \\ Madrasah Aliyah Ridho Ilahi Soreang Desa Tamalate \\ Kecamatan Galesong Utara Kabupaten Takalar
}

\begin{abstract}
Abstrak: Tulisan ini mengkaji tentang perilaku dalam kaitannya dengan masyarakat nelayan. Jenis penelitian ini adalah kualitatif deskriptif pada lokasi di Desa Tamalate Kecamatan Galesong Utara Kabupaten Takalar. Fokus penelitian adalah perilaku nelayan dalam lingkungan keluarga terhadap pendidikan anak. Pendekatan yang digunakan peneliti dalam penelitian ini adalah pendekatan fenomenologis. Sumber data dalam penelitian ini adalah orang tua nelayan, anak nelayan. punggawa, sawi atau buruh nelayan. Pengumpulan data dilakukan dengan metode observasi, wawancara, dan dokumentasi dengan instrumen pedoman observasi, pedoman wawancara dan alat-alat dokumen seperti kamera dan lain-lain. Data yang terkumpulkan dianalisis dengan cara reduksi data, penyajian data, dan verifikasi data. Untuk mendapatkan data yang absah, maka diuji dengan cara ketekunan pengamatan, trianggulasi, dan Pengecekan anggota (member checks).

Hasil penelitian menunjukkan bahwa perilaku keluarga nelayan dalam Pendidikan Anak di (informal) Desa Tamalate Kecamatan Galesong berdasarkan hasil temuan, bahwa: (a) Keluarga nelayan melakukan ritual-ritual appasili dengan melibatkan keluarga dan tetangga (b) Orang tua nelayan melakukan ritual/upacara kelahiran (appatompolo) yang bernuangsa keagamaan melaui upacara akikah.(c). Orang tua nelayan telah membiasakan anak-anak melaut pada usia dini 8-12 tahun (d) Pendidikan kegamaan yang diwarikan kepada anak dilakukan secara turun temurun (e) Keluarga nelayan melakukan upacara adat dan melakukan persembahan dengan cara memberikan sesajen kepada yang diyakini bisa memberi barakah pada saat turun melaut.
\end{abstract}

\section{Keywords: Perilaku Nelayan, Pendidikan Anak Nelayan}

\section{PENDAHULUAN}

Keluarga adalah salah satu mata rantai kehidupan yang sangat esensial dalam perjalanan hidup anak. Setiap orang tua tentu menginginkan yang terbaik bagi anakanaknya. Usaha untuk menjadikan anak yang lebih baik salah satu faktor pembentuknya adalah suasana keluarga yang kondusif serta dapat mendukung perkembangan anak.

M. Rutter juga menunjukkan fakta tentang interaksi orang tua dan anak, Rutter menyebutkan bahwa: (1) Hubungan yang baik dalam keluarga antara anak dan orang tua dan antara ayah dan ibu dapat mencegah anak berperilaku agresif dan hubungan yang tidak harmonis di antaranya membuat anak berperilaku agresif. (2) Orang tua yang selalu memberikan kecaman dan ancaman terhadap anak membuat anak berperilaku agresif dan orang tua yang sering memberikan penghargaan kepada anak dapat 
membuat anak tidak berperilaku agresif. (3) Hubungan antara suami istri yang harmonis membuat anak tidak berperilaku agresif dan ketidakharmonisan hubungan antara ayah dan ibu membuat anak berperilaku agresif. ${ }^{1}$

Fakta di atas menunjukkan bahwa interaksi dalam pendidikan keluarga harus dibangun dengan pendekatan demokratis sehingga akan terjalin komunikasi yang dialogis antara anak dan orang tua. Walaupun hakekat pembentukan kepribadian anak terjadi dalam masa yang sangat panjang, yaitu sejak ia dalam kandungan, kehidupan sehari-hari bersama orang tua dan sanak saudara, sekolah, dan masyarakat. Idealnya semuanya harus terhindar dari tindak otoritatif dan penindasan psikologis.

Membina anak bukan hanya dengan memberi nama yang baik, memberi makanan yang cukup, pakaian yang pantas, perlindungan yang harmonis, akan tetapi mereka harus dibekali dengan kecerdasan, keterampilan, cinta tanah air, yang dilandasi iman dan taqwa. Kesemua itu diproses dalam pendidikan yang merupakan suatu komponen yang sangat penting dimiliki oleh setiap anak dalam mewujudkan cita-cita kemerdekaan. $^{2}$

Orang tua harus mempunyai pengetahuan yang cukup tentang bagaimana cara mendidik anak dengan mempertimbangkan dan memperhatikan perkembangan jiwa anak secara baik. Begitu berat tanggung jawab yang dibebankan kepada orang tua, tentunya harus menjadi perhatian yang besar tentang bagaimana cara pandang orang tua tentang mendidik anak.

Salah satu model keluarga dari aspek pekerjaan adalah keluarga nelayan. Nelayan adalah masyarakat yang memiliki mata pencarian utama sebagai penangkap ikan. Mereka pada umumnya tinggal di pinggir pantai, sebuah lingkungan pemukiman yang dekat dengan lokasi kegiatannya. Hakekatnya nelayan adalah golongan masyarakat yang masih perlu diberdayakan dan harkat hidup mereka perlu diangkat. Pada umumnya kehidupan nelayan selalu diungkapkan dengan keterbelakangan baik dari sudut pandang pencaharian, maupun cara berpikir, dan sikap atau perilaku yang masih tradisional.

Dengan kondisi ini para nelayan relatif masih mengalami kesulitan membutuhi kehidupan keluarga. Dalam satu keluarga, kehadiran anak menjadi sesuatu yang tidak ternilai harganya. Dengan demikian anak membutuhkan cinta kasih dari orang tua, memerlukan lingkungan yang sehat untuk tumbuh berkembang secara wajar. Kelangsungan hidup seorang anak, perlindungan dan pengembangan dirinya merupakan hak seorang anak dalam keluarga, dan menjadi kewajiban, tanggunng jawab ayah dan ibu sebagai orang tua. Kita dapat melihat betapa besar, tanggung jawab keluarga dalam proses perkembangan anak, karena kelurga mempunyai peranan penting dalam mempersiapkan anak-anak untuk mencapai masa depan yang baik bagi dirinya sendiri, keluarga serta orang lain.

Demikian juga yang penulis amati waktu observasi di lapangan bahwa keadaan pendidikan anak usia sekolah di Desa Tamalate cukup memprihatinkan karena pada umumnya pendidikan anak masih rendah. Pada dasarnya jika berbicara mengenai masalah pendidikan anak, maka alasan yang dilontarkan oleh orang tua mengapa anak mereka tidak sekolah adalah karena keadaan ekonomi sehingga tidak pernah terpikirkan untuk menyekolahkan anak ke jenjang yang lehih tinggi. Kebanyakan orangtua yang

\footnotetext{
${ }^{1}$ Mohammad Shochib, Pola Asuh Orang Tua dalam Membentuk Anak Mengembangkan Disiplin Diri (Cet. I; Jakarta: Rineka Cipta, 2000), h. 5.

${ }^{2}$ Paulus Mujiran, Pernik-Pernik Pendidikan Manifestasi dalam Keluarga, Sekolah dan Pentadaran Geder (cet I, Yogyakarta; Pustaka Pelajar, 2002), h. 32
} 
berpencaharian sebagai nelayan pada umumnya pendidikan mereka pada tingkat SD bahkan ketika penulis observasi di lapangan bahkan sangat banyak nelayan yang buta huruf dan tidak tahu membaca .

Dengan kondisi tersebut penulis berasumsi bahwa para nelayan pada umumnya belum memahami dan mengerti akan pentingnya pendidikan anak (formal). Artinya dengan kondisi demikian sangat banyak orangtua yang kurang berprilaku positif untuk mengecap pendidikan karena prinsip yang masih melekat dipikiran mereka bahwa sekolah bukan sesuatu hal yang menjanjikan untuk memperbaiki hidup. Pada hal jika dikaji lebih dalam bahwa melalui pendidikan anak nasib keluarga akan bisa diperbaiki.

Jika dilihat dari pendapatan orang tua yang bermata pencaharian sebagai nelayan pada umumnya pendapatan yang mereka peroleh relatif tidak akan cukup untuk menyekolahkan anaknya kejenjang yang lebih tinggi. Jika dibandingkan dengan pendapatan petani dan nelayan maka pendapatan yang didapatkan setiap bulanya dapat dikatakan tidaklah berbeda jauh bahkan pendapatan relatif lebih banyak. Tetapi pada kenyataanya anak petani relatif dapat mengecap pendidikan sampai tingkat SMA, bahkan ada juga sampai ke perguruan tinggi. Sedangkan pada masyarakat nelayan masih banyak sekali anak mereka yang tidak sekolah di tingkat SMA apalagi lanjut di perguruan tinggi. Ketimpangan ini terjadi sebagai akibat dari perilaku orang tua yang tidak memahami pentingya pendidikan bagi anak-anak mereka.

Kondisi kemiskinan dan kesenjangan sosial ekonomi dalam kehidupan masyarakat nelayan khusunya di Pulau yang berhadapan dengan daratan Kabupaten Takalar merupakan gambaran masyarakat nelayan bermata pencaharian sebagai nelayan termasuk dalam kategori masyarakat miskin. Hal ini dapat terlihat dari fakta-fakta fisik berupa kualitas pemukiman masih tidak layak. Salah satu ciri tingkat kelayakan lantai rumah bisa dilihat berdasarkan lantai yang dimilikinya dinding rumah yang digunakan.

Menurut asumsi peneliti sehubungan pernyataan tersebut, bahwa hal ini berdampak pada pendidikan anak-anak mereka. Sebab sebagian besar waktu orang tua dihabiskan untuk mencari nafkah, sehingga mereka mengabaikan tanggung jawab mereka dalam mendidik anak-anak mereka. Sekalipun disadari bahwa pemenuhan kebutuhan ekonomi keluarga harus mendapat perioritas utama, akan tetapi mestinya berbanding lurus dengan perioritas memberikan perhatian dalam pendidikan anak. Selain kendala tersebut, faktor ekonomi merupakan salah satu kendala yang sangat berpengaruh dalam pendidikan anak. Tamsil Linrung, menyatakan bahwa ketertinggalan dan kemiskinan nelayan disebabkan oleh beberapa faktor, diantaranya tidak ada akses ke sumber modal, akses terhadap teknologi dan terhadap pasar." ${ }^{3}$

Demikian pula halnya nelayan di Desa Tamalate, selain faktor-faktor di atas, ketertinggalan mereka juga disebabkan karena faktor sosial seperti pertumbuhan jumlah penduduk yang tinggi dan rendahnya tingkat pendidikan. Ketertinggalan nelayan juga disebabkan karena hanya mengelola sumber daya konvensional seperti jenis-jenis ikan tertentu saja dan tidak mampu memanfaatkan sumber daya non-konvensional (nonikan). Sebagian besar anak-anak nelayan di Desa Tamalate masih berpendidikan relatif rendah yaitu hanya sampai tingkat sekolah dasar, bahkan ada juga yang tidak lulus sekolah dasar sehingga tidak memiliki keterampilan hidup baik dari segi komunikasi, informasi, mental, pembentukan jati diri dan kepercayaan diri yang cenderung memengaruhi pola pikir anak serta membawa diri anak kembali ke arah tradisi mereka sendiri yaitu memilih mengikuti jejak orang tua mereka sebagai nelayan. Itu bisa dilihat

\footnotetext{
${ }^{3}$ Tamsil Linrung, Potret Ketertinggalan Nelayan Kita (t..tp: Hanana Press, 2007), h. XIV.
} 
dalam melaut waktu yang dibutuhkan nelayan Desa Tamalate untuk mencari ikan bervariasi, ada yang sehari, tiga hari, satu minggu, dan bahkan ada yang sampai 5 bulan (patorani).

Selain hal di atas, yang menjadi alasan lain melatarbelakangi penelitian ini adalah karena studi tentang perilaku dalam kaitannya dengan masyarakat nelayan dalam pendidikan anak masih sangat terbatas. Di samping itu, konsep-konsep tentang perilaku dalam kaitan fokus penelitian ini sangat berharga dalam dunia pendidikan. Selain itu, perilaku keluarga nelayan terhadap pendidikan anak masih relatif rendah sebagai indikator masih banyaknya anak-anak yang ditemukan putus sekolah.

\section{KAJIAN TEORITIK}

\section{A. Tinjauan tentang Perilaku /Sikap Keluarga Nelayan}

Perilaku/behavior berati daya yang ada pada diri manusia yang teraktualiasi dalam bentuk perbuatan yang ditimbulkan karena adanya faktor internal dan faktor eksternal atau pengaruh dari luar diri kita. ${ }^{4}$ Sdangkan sikap adalah kesiapan dari psike untuk bertindak atau bereaksi dengan cara tertentu. Sikap adalah perasaan orang tentang obyek, aktivitas, peristiwa dan orang lain. Perasaan ini menjadi konsep yang mempresentasikan suka atau tidak suka (positif, negatif, atau netral) seseorang pada sesuatu. Sikap dikembangkan dalam tiga model, yaitu afeksi, adalah respon fisiologis, yang mengekspresikan kesukaan individu. Bisa terdapat kaitan antara sikap dan perilaku seseorang walaupun tergantung pada faktor lain, yang kadang bersifat irrasional.

Keluarga nelayan yang mata pencaharian utamanya adalah menangkap ikan. ${ }^{6}$ Umumnya nelayan baru yang memulai usahanya dari bawah. Masyarakat nelayan paling sedikit memiliki lima karakteristik yang membedakan dengan petani pada umumnya. Kelima karakteristik itu adalah: (1) Pendapatan nelayan bersifat harian dan jumlahnya sulit ditentukan. Selain itu pendapatannya juga sangat tergantung pada musim dan status nelayan itu sendiri. ( 2) Dilihat dari pendidikannya, tingkat pendidikan nelayan maupun anak-anak nelayan pada umumnya rendah. ( 3 ) Dihubungkan dengan sifat produk yang dihasilkan nelayan maka nelayan lebih banyak berhubungan dengan ekonomi tukar-menukar, karena produk tersebut bukan merupakan makanan pokok.( 4) Bahwa dibidang perikanan membuktikan investasi yang cukup besar dan cenderung mengandung resiko yang lebih besar jika dibandingkan dengan sektor lainnya. (5) Kehidupan nelayan yang miskin juga diliputi oleh kerentanan, misalnya ditunjukkan oleh terbatasnya anggota keluarga yang secara langsung dapat ikut dalam kegiatan produksi dan ketergantungan nelayan yang sangat besar pada satu mata pencaharian yaitu menangkap ikan.

Keluarga nelayan adalah orang yang menggantungkan hidupnya pada sumber daya laut yaitu melalui kegiatan menangkap ikan. Rumah tangga nelayan pada umumnya memiliki persoalan yang kompleks dibandingkan dengan rumah tangga

\footnotetext{
${ }^{4}$ Wahyuni, Perilaku Beragama Studi Sosiologi terhadap Asimilasi Agama dan Budaya di Sulawesi Selatan, Cet. I: Tahun 2003), h.1

${ }^{5}$ Wahyuni, Perilaku Beragama Studi Sosiologi terhadap Asimilasi Agama dan Budaya, h. 5.

${ }^{6}$ Masyhuri, Strategi Pengembangan Desa Nelayan Tertinggal, Organisasi Ekonomi Masyarakat Nelayan. Jakarta. Publitbang Ekonomi dan Pembangunan Lembaga Ilmu Pengetahuan Indonesia (PEPLIPI), 1998. h, 21

${ }^{7}$ Kusnadi, Nelayan, Strategi Adaptasi dan Jaringan Sosial. (Bandung: Humaniora Utama Press, 2000), h. 45.
} 
petani. Rumah tangga nelayan memiliki ciri-ciri khusus seperti penggunaan wilayah pesisir dan lautan sebagai faktor produksi, pendapatan sulit ditentukan karena tergantung pada musim dan status nelayan, pendidikan nelayan relatif rendah, dan nelayan membutuhkan investasi yang besar tanpa mengetahui hasil yang akan dicapai untuk menginterpretasi dan memaknai berbagai peristiwa yang terjadi dilingkungannya bersifat fungsional. ${ }^{8}$

Adapun ciri-ciri perilaku soial nelayan, peneliti menguraikan sebagai berikut 1 . Etos keja sangat tinggi dalam memenuhi kebutuhan hidup dan mencapai kemakmuran 2. Solidaritas yang kuat dalam menghadapi ancaman bersama atau membantu sesama ketika mendapat musibah 3. Bergaya hidup komsumtif. 4. Temperamental khususnya jika terkait dengan harga diri. 5. Agamis dengan sentimen keagamaan yang tinggi 6 . Apresiai terhadap prestasi seseorang dan penghargai keahlian 7. Kompetitif dan mengandalkan kemampuan diri sendiri dalam mencapai keberhasilan 8. Kemampuan adaptasi dan bertahan hidup yang tinggi. 9. Demontratif dalam masalah harta, seperti emas, perabotan, kendaraan, bangunan rumah, agama. Salah satu ciri perilaku sosial dari masyarakat pesisir yang terkait dengan sikap tempramental dan harga diri tersebut dapat disimak dalam pernyataan antropolog Belanda di bawah ini.

Orang pesisir memilki orientasi yang kuat untuk merebut dan meningkatkan kewibawaan atau status soaial. Mereka sendiri mengakui bahwa mereka cepat marah, mudah tersinggung, lekas menggunakan kekerasan, dan gampang cenderung balas membalas sampai dengan pembunuhan. Orang pesiir memiliki rasa harga diri yang amat tinggi dan sangat peka. Perasaan itu bersumber pada kesadaran mereka bahwa pola hidup pesisir memang pantas mendapat penghargaan yang tinggi. ${ }^{9}$

\section{B. Pendidikan dalam Keluarga}

Pendidikan yang diperoleh anak dalam keluarga disebut dengan pendidikan informal. Konsep implementasi pendidikan scara informal perspektif Islam adalah berdasarkan masa atau fase-fase perkembangan itu sendiri. Artinya proses pendidikan itu disesuaikan dengan pola tempo, serta irama perkembangan dan adanya kehidupan setelah adanya roh dari Allah swt. Masa dalam kandungan atau biasa disebut masa aljanin adalah masa anak berada dalam kandungan dan adanya kehidupan setelah adanya roh dari Allah swt. ${ }^{10}$ Pada usia janin 4 bulan, pendidikan diterapkan dengan istilah pranatal. Di sini ibu sebagai orang tua yang mengandung anak, hendaklah mempersiapkan kondisi fisik maupun psikisisnya, sebab hal itu sangat menentukan dari pengaruh terhadap proses kelahiran anak nanti. Selain komsumsi makanan, ketenangan emosional ibu juga perlu dipelihara. Hal lain yang perlu dilakukan adalah orang tua perlu berzikir dan membacakan doa-doa penting bagi janin dalam kandungan. Disamping itu, ayah juga dianjukan untuk senantiasa berzikir dan membacakan doa-doa penting bagi janin bacaan dalam kandungan. Dalam. kaitan ini, maka bacaan yang perlu dibaca adalah ayat kursi. Ini dikemukakan oleh salah seoang pendapat. ${ }^{11}$

\footnotetext{
${ }^{8}$ Roger M. Kessing, Antropologi Budaya, Suatu Perspektif Kontemporer (Jakarta: Erlangga, 1989), h. 68-69.

${ }^{9}$ Yang Boelaars, Kepribadian Indonesia Moderen: Suatu Penelitian Antropologi Budaya (Jakarta: Gramedia, 1984), 62

${ }^{10}$ Zaenuddin et.al, Seluk Beluk Pendidikan dari al-Ghazali (Cet, I, Jakarta: Bumi Aksara, 2001), h. 69

${ }^{11}$ Demikian yang dikemukakan Jmal Abdul Rahman, Aifhfal al Muslimin Kaifa Rabbahum Nabiyy al-Amiin ( Makkah al-Mukarramah: Dar al-Taybah al- Khadra, 2000), h. 40
} 
Pertumbuhan dan perkembangan anak akan berfungsi dengan baik, jika pendidik memahami periodesasi dan fase pendidikan anak. Karena dalam setiap periode dan fese pertumbuhan dan perkembangan anak mempunyai ciri khas tersendiri dan membutuhkan penanganan yang berbeda disetiap periode dan fase-fase masing-masing.

1. Periode Pendidikan Anak

a. Fase Prakonsepsi

Prakonsepsi adalah suatu upaya persiapan pendidikan anak. ${ }^{12}$ Kaidah dasar masa prakonsepsi ini adalah ungkapan Imam al-Gazali "didiklah anakmu sebelum ia lahir" beragam penafsiran dalam menafsirkan ungkapan ini,ada yang berpendapat masa ini dimulai sejak seorang memilih pasangan hidup. Pendapat yang lain mengatakan jauh sebelum menikah Islam mengajarkan para calon orang tua untuk mempersiapkan dirinya dan memperbaiki agama dan akhlaknya, karena Allah swt. mengisyaratkan bahwa wanita yang baik hanya untuk laki-laki yang baik dan laki-laki yang baik hanya untuk wanita yang baik pula.Q.S. al-Nur/24:26:

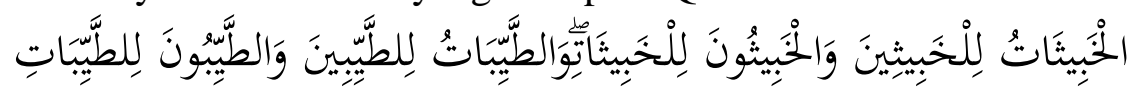

Terjemahnya:

Wanita-wanita yang keji adalah untuk laki-laki yang keji, dan laki-laki yang keji adalah buat wanita-wanita yang keji (pula), dan wanita-wanita yang baik adalah untuk laki-laki yang baik dan laki-laki yang baik adalah untuk wanita-wanita yang baik (pula).

\section{b. Fase Prenatal}

Periode prenatal atau masa sebelum lahir adalah periode awal perkembangan manusia yang dimulai sejak konsepsi, yakni ketika ovum wanita dibuahi oleh sperma laki-laki sampai dengan waktu kelahiran seseorang. ${ }^{13}$ Masa ini pada umumnya berlangsung selama 9 bulan.Dilihat dari segi waktunya, periode prenatal ini merupakan periode perkembangan manusia yang paling singkat, tetapi justru pada periode ini dipandang terjadi perkembangan yang sangat cepat dalam diri individu. ${ }^{14}$ Periode pendidikan anak masa prenatal adalah upaya pendidikan yang dilakukan orang tua pada saat anak masih berada dalam kandungan. Agnes mengatakan bahwa genetik dan asupan makanan saat hamil diindikasisebagai faktor penting dalam pembentukan intelegensi anak. ${ }^{15}$ Walaupun hubungan antara dua variabel tersebut hingga saat ini masih dicari kepastiannya di pengembangan riset, namun banyak sekali narasumber dan di area ini membuktikan bahwa faktor genetik dan hereditas diyakini mempengaruhi tingkat kecerdasan seseorang. Banyak juga riset yang membuktikan bahwa susunan genetik atau blueprient genetic akan sangat memengaruhi tingkat kecerdasan seseorang.

Faktor makanan dan nutrisi juga merupakan faktor penting yang berpengaruh besar dalam pembentukan janin pada saat ibu mengandung. Terpenuhinya nutrisi yang cukup tentu akan membentuk pertumbuhan janin yang sehat. ${ }^{16}$

\footnotetext{
${ }^{12}$ Wahjoetomo, Perguruan Tinggi Pesantren Pendidikan Alternatif Masa Depan (Ttc. Jakarta: Gema Insani Press, 1997), h. 24.

${ }^{13}$ Desmita, Psikologi Perkembangan (Cet. V, Bandung: Remaja Rosdakarya, 2009), h. 69.

${ }^{14}$ Desmita, Psikologi Perkembangan, 2009, h. 69.

${ }^{15}$ Agnes Tri Harjanigrum, Peranan Orang Tua dan Praktisi dalam Membantu Tumbuh Kembang Anak Berbakat Melalui Pemahaman Teori dan Tren Pendidikan (Cet. I; Jakarta: Prenada Media Grup, 2007), h. 26.

${ }^{16}$ Desmita, Psikologi Perkembangan (Cet. V, Bandung: Remaja Rosdakarya, 2009), h. 69.
} 
Riset terbaru menunjukkan bahwa janin juga telah mampu mendengar atau responsip terhadap stimuli dari lingkungan eksternal, terutama terhadap suara.Dalam suatu studi mengenai kemampuan janin merespon rangsangan eksternal, Dr. Saus's meminta kepada ibu-ibu hamil untuk membaca sebuah cerita anak-anak "The Cat in the Hat" dengan suara nyaring kepada bayi yang dikandungnya sebanyak dua kali sehari selama enam minggu terahir kehamilannya. Beberapa hari setelah lahir, kemudian bayi kembali diperdengarkan pada cerita yang sama dan sebuah cerita yang lain yang belum pernah diperdengarkan sebelumnya. Untuk menentukan cerita mana yang lebih ia sukai, bayi diberi sebuah dot yang dapat merekam setiap perubahan dan peningkatan atau penurunan interval waktu menyusu. Ternyata, perubahan kecepatan dan peningkatan menyusui terjadi pada waktu bayi mendengar cerita "The Cat in the Hat"tetapi hal demikian tidak terjadi pada waktu mendengarkan cerita baru. Jadi, bayi menunjukkan suatu pilihan yang jelas bardasarkan pada pengalamannya selama masa prenatal. ${ }^{17}$

Sebuah penelitian menunjukkan bahwa lebih dari 50\% otak manusia tumbuh dan berkembang di usia balita. Kondisi otak bayi ketika berusia 18 bulan fisik otak telah mencapai $50 \%$ dari ukuran otak orang dewasa, fisik otak mencapai $90 \%$ dari ukuran otak orang dewasa ketika anak berusia 6 tahun. Selanjutnya ukuran otak mencapai $100 \%$ ukuran otak orang dewasa saat anak berusia 18 tahun. ${ }^{18}$ Dengan demikian, memberikan pemenuhan gizi anak pada usia balita bahkan semasa dalam kandungan sangat penting dalam menentukan pertumbuhan fisik dan otak anak. Pemenuhan gizi hendaknya menjadi prioritas bagi oang tua bila hal ini terabaikan bisa berakibat pada kurang optimalnya pertumbuhan otak.

Melihat potensi perkembangan fisik dan intelektual anak yang begitu pesat di usia dini, Karno Suprapto berpendapat sebagaimana yang dikutip oleh Imam Musbikin bahwa anak sudah bisa dididik sejak usia kandungan 12 minggu atau 3 bulan. Pada usia ini bayi sudah bisa menerima rangsangan pada panca indranya. Rangsangan ini akan diterima anak terutama lewat pendengarannya. ${ }^{19}$ Jadi pendidikan anak prenatal dapat dilakukan dengan berkomunikasi dengan bayi dengan cara memperdengarkan kepadanya ayat-ayat al-Qur'an, z|ikir, musik-musik, mengajaknya bercakap dan sebagainya dapat merangsang pertumbuhan otaknya. Alangkah baiknya bila bacaan alQur'an, zikir, dan percakapan dengan janin, dilakukan dengan penghayatan yang bersumber dari nurani yang penuh rasa cinta dan kasih sanyang kepadanya. Getaran tersebut akan terdengar oleh indra pendengarannya, dan akan membekas serta berpengaruh terhadap janin setelah dilahirkan. Dengan demikian dapat dipahami kenapa orang tua laki-laki (Ayah) dianjurkan untuk berpuasa ketika bayi masih dalam kandungan.

Hal senada disampaikan oleh Agnes Tri Harjanigrum, menurutnya kecerdasan anak tidak hanya ditentukan oleh faktor gizi ketika anak dalam kandungan, tetapi faktor nutrisi dan gizi saat anak mengalami proses tumbuh kembang juga berpengaruh besar terhadap pertumbuhan dan kecerdasan anak. ${ }^{20}$ dalam Islam tentu tidak cukup dengan nutrisi dan gizi, makanan disamping bernutrisi dan bergizi yang tidak kalah penting adalah makanan tersebut harus halal dan baik.

\footnotetext{
${ }^{17}$ Agnes Tri Harjanigrum, Peranan Orang Tua dan Praktisi dalam Membantu Tumbuh Kembang Anak Berbakat Melalui Pemahaman Teori dan Tren Pendidikan, 2007, h. 26.

${ }^{18}$ Imam Musbikin, Mendidik Anak Ala Shincan (Cet. II; Yogyakarta: Mitra Pustaka, Tth), h. 49.

${ }^{19}$ Imam Musbikin, Mendidik Anak Ala Shincan, h. 49.

${ }^{20}$ Agnes Tri Harjanigrum, Peranan Orang Tua dan Praktisi dalam Membantu Tumbuh Kembang Anak Berbakat Melalui Pemahaman Teori dan Tren Pendidikan, 2007, h. 26.
} 
Unsur lain seperti genetika, sosial, kesehatan, dan lingkungan jugasangat berpengaruh terhadap pertumbuhan kecerdasan anak.Menciptakan suasana keluarga yang dipenuhi rasa cinta dan kasih sayang, harmonis, akrab, dan saling peduli antara anggota keluarga tentu sangat berpengaruh terhadap perkembangan otak anak.Selanjutnya yang menjadi kunci keberhasilan dalam pendidikan anak terutama periode pranatal adalah keikhlasan dari semua pihak terutama ayah dan ibu.Demikian pula sebaliknya perkelahian, cekcok dan ketidak harmonisan antara ayah dan ibu ketika hamil dapat menghambat tumbuh kembang fisik ataupun psikis anak, bahkan akan berakibat fatal.

\section{c. Fase Post Natal}

Postnatal adalah pendidikan anak dimulai sejak lahir. sampai dewasa bahkan hingga wafatnya, yang dikenal dengan istilah pendidikan semur hidup. ${ }^{21}$

1) Fase awal masa kanak-kanak

Pada saat bayi dilahirkan berarti ia pindah dari alam rahim atau alam kandungan ibu ke alam dunia ini. Islam menegaskan bahwa semua bayi lahir dalam keadaan fitrah. Untuk mempertahankan fitrahnya, maka langkah awal yang dilakukan adalah penanaman kepribadian muslim dengan cara mempertahankan fitrahnya. Maka langkah awal yang dilakukan adalah pemahaman kepribadian muslim dengan cara memperdengankan azan. Rahasia azan yang diperdengarkan pada telinga bayi yang baru lahir mengandung harapan optimis agar mula-mula suara di dengar oleh telinga sang bayi adalah keagungan dan kebesaran Allah dan kemuliaan nabin-Nya dalam simbol syahadat. Itu berarti bahwa kepribadian rabbani, rasuli, syahadatayn sudah harus mulai tertanam pada diri bayi. Tuntunan pendidikan seperti ini sekaligus menjadi perlambang Islam bagi seorang bayi.

Dari aspek psikologi kepribadian, bayi pada tahap ini yakni di hari-hari pertama kelahirannya, memang belum memiliki kesadaran dan daya intelektual . Ia hanya mampu menerima ransangan yang bersifat biologis dan psikologis melalui air susu ibunya. Karena demikian halnya, maka dalam fase ini interaksi edukatif belum dapat diterapkan secara langsung, kecuali dengan mengazankan ditelinganya. Pengaruh azan tersebut dapat menembus kalbu sang bayi yang bersangkutan belum dapat menyadarinya. $^{22}$

Pada hari akikahnya (hari ke tujuh) juga dianjurkan untuk mencukur rambut bayi, membersihkan, dan menghilangkan kotoran darinya. Anjuran semacam ini, adalah merupakan untutan fitrah yng berasas pada simbol keislaman yang mengumatakan kebersihan dan keindahan. Masa bayi, terutama ketika berusaha antara enam sampai enam bulan sudah mulai dapat berkomunikasi dengan satu kata atau dua kata. Demikian seterusnya sampai dua tahun tahun sudah dapat menyusun kalimat.

Kelahiran merupakan kejadian yang sangat penting bagi perkembangan manusia.Menurut Otto Rank, bagi sang bayi, kelahiran merupakan keadaan tidak menyenangkan yang membekas secara mendalam (trauma), ia seolah dipaksa keluar dari kandungan sebagai dunia yang aman dan tempat berlindung dari bahaya eksternal. Oleh karena itu, bayi kemudian menangis.

Agar dapat mengembangkan potensi dan kelebihan-kelebihan yang ada dalam dirinya, Islam mengajarkan bagaimana mendidik dan mengembangkan potensi

\footnotetext{
${ }^{21}$ Agnes Tri Harjanigrum, Peranan Orang Tua dan Praktisi dalam Membantu Tumbuh Kembang Anak Berbakat Melalui Pemahaman Teori dan Tren Pendidikan, 2007, h. 45.

22 Syaripuddin Ondeng, Menyorot Lembaga Pendidikan Islam, Era Global Studi Kritis Terhadap Manajemen Madrasah di Era Informasi dan Komunikasi, Cet;I; Alauddin Pess, 2014, h.100
} 
tersebut.Karena secara keseluruhan manusia semuanya adalah baik, dan berhak mendapatkan sesuatu yang baik. ${ }^{23}$.

Azan dan iqamat yang berisi pokok-pokok ketauhidan, kalimat-kalimat tauhidlah yang pertama kali meresap ke dalam sanubarinya sebelum ia mendengar bunyi-bunyi yang lain. Mengazani dan mengiqamati bayi bertujuan supaya kalimat az|an dan qamat menjadi kalimat yang pertamakali didengar oleh bayi, dimana kalimat az|an mengandung kebesaran Allah swt.dan keagungannya, dan merupakan penyaksian bagi bayi tersebut bahwa ia diIslamkan. ${ }^{24}$ Bacaan azan dan iqamat merupakan kalimat syiar Islam dan setan akan lari terbirit-birit ketika mendengar kalimat tersebut dan setan mendengar sesuatu yang ia benci pada awal kehidupan sang bayi.Hal ini sangat penting, sebagaimana para psikolog menjelaskan apa yang didengar, dilihat dan dirasakan oleh seorang anak sewaktu kecil akan terpatri kuat dalam jiwanya danterpengaruh besar bagi perkembangan kepribadiannya.

Hal berikutnya yang sangat penting dalam membentuk kepribadian dan ketauhidan adalah memberi nama yang baik dan Islami. Nama memiliki pengaruh yang besar bagi pembentukan kepribadian anak. Ada beberapa hal yang dapat diungkapkan dalam soal nama. Pertama, nama adalah lambang kepribadian orang tua sebagai pemberi nama dan identitas bagi keluarganya. ${ }^{25}$ Dari nama anak dapat diprediksikan tipe keluarganya, sebab pemberian nama biasanya berhubungan erat dengan identitas keluarga, dan etnis. Kedua, nama adalah misi, pesan atau tujuan yang ingin dicapai orang tua. Ketiga, nama yang baik dapat memberikan hubungan dan pengaruh psikologis yang kuat terhadap anak, dan nama yang buruk membuat anak menjadi minder dalam pergaulan.

Selanjutnya untuk memenuhi kebutuhan biologis, bayi perlu diberi air susu ibu (ASI). ASI adalah hak bayi dan kewajiban bagi ibu untuk memberikannya.ASI merupakan nutrisi terbaik yang tidak bisa digantikan dengan yang lainnya.Disamping itu kedekatan dan kebutuhan emosi anak bisa terpenuhi pada saat anak menyusui.

Menurut Hiromi Shinya susu formula merupakan produk dari susu sapi yang sudah terkontaminasi oleh oksigen (teroksidasi), sehingga telah kehilangan seluruh sifat baiknya, oleh karenanya kurang baik untuk bayi. Susu sapi walaupun sebagai susu segar yang masih mentah, bukanlah makanan yang cocok bagi manusia, dan pada dasarnya susu sapi hanya untuk anak sapi. ${ }^{26}$

Perkembangan jasmani merupakan dasar dalam perkembangan mental, Perkembangan mental akan berjalan dengan baik apabila perkembangan fisik juga baik. Fase masa kanak-kanak dinamakan juga fase prasekolah. Pada masa ini sebagaian besar waktu anak berlangsung di rumah dalam pengawasan keluarga. Para ahli ilmu jiwa dan kesehatan menganggap dua tahun pertama ini merupakan dasar pertumbuhan anak yang sangat penting dalam pertumbuhan dan perkembangan anak selanjutnya, karena pada masaini terjadi pertumbuhan jasmani, akal dan perasaan.

Berbicara dan berjalan merupakan dua faktor yang mengiringi pertumbuhan anak. Melalui berbicara anak dapat berhubungan dan berinteraksi dengan orang lain,

${ }^{23}$ Brian Tracy, Change Your Thingking, Change Your Life, Bebaskan Potensi Dashat Anda untuk Kesuksesan yang Tak Terbatas, (Cet. III, Bandung, Mizan Pustaka, 2007), h. 28

${ }^{24}$ Jalal Abdurrahman, Pendidikan Ala Kanjeng Nabi (Cet. I; Jogjakarta: Mitra Pustaka, 2003), h.

11.

${ }^{25}$ Jalal Abdurrahman, Pendidikan Ala Kanjeng Nabi, 2003, h. 11.

${ }^{26}$ Hiromi Shinya, The Miracle of Enzyme (Cet. X; Bandung: Mizan Media Utama, 2009), h. 128. 
dengan berinteraksi dan komunikasi akan memberikan pengalaman yang dapat merangsang pertumbuhan otak. Sedangkan berjalan dapat melatih otot dan dengan aktifitas otot akan merangsang motorik anak.

Kepada anak yang baru belajar berbicara alangkah baiknya bila orang tua mengajarkan kalimat-kalimat tauhid menurut Ibnu Qayyim al-Jauziyah ketika anak belajar berbicara hendaklah anak-anak diajarkan kalimat La ilahailallah Muhammad Rasulallah, dan hendaknya kalimat-kalimat pertama yang menembus pendengaran mereka adalah kalimat-kalimat yang mengandung nilai-nilai Syiar Islam dan ma'rifat kepada Allah. $^{27}$

Pembentukan kepribadian (keagamaan) anak harus dilakukan sedini mungkin, terutama dengan pembiasaan.Dengan menciptakan kebiasaan-kebiasaan yang baik berarti telah membentuk kepribadian yang baik. Anak yang dibiasakan dengan memberi input agamis, misalnya membiasakan membaca do'a sebelum tidur, membaca bismillah sebelum makan dan mengucapkan salam bila memasuki rumah. Ini dikarenakan anak pada umumnya lebih mudah menerima apa yang dilihat dari pada yang diperintahkan, maka dalam pembentukan moral keagamaannya, harus pula dibarengi dengan tauladan dari orang tua. ${ }^{28}$

Menurut al-Nahlawi, keteladanan termasuk salah satu dari sekian banyak metode pendidikan Islam. Metode lain misalnya tauziyah (nasehat yang baik), perumpamaan-perumpamaan, penyampaian kisah-kisah, dialog, dan melalui praktik langsung juga dilakukan disesuaikan dengan kondisi objek yang dihadapi oleh Rasulallah saw. Pada masa awal pengembangan Islam Rasulullah saw.banyakmemberikan teladan disamping ucapan. Ketika Allah memerintahkan sedekah maka Rasulullah saw.yang pertama kali membayarnya. Begitu juga ketika Allah swt. menganjurkan shalat malam, beliaulah yang pertama dan paling rajin menegakkannya. Sehingga para sahabat tidak membantah atau ragu melakukannya, sebab mereka menyaksikan keteladanan Rasulullah saw.dalam mengamalkan ajaran Islam. ${ }^{29}$

Pendidikan anak dalam keluarga adalah tanggung jawab orang tua terutama ibu sesuai kodratnya sebagai perempuan, yakni memiliki sifat-sifat lembut, sabar, telaten, dan kasih sayang yang besar terhadap anaknya, memungkinkan seorang ibu melaksanakan tugas tersebut.Berbeda dengan laki-laki (ayah) yang umumnya bersifat keras, otoriter, juga sibuk mencari nafkah, sehingga kurang memungkinkan melakukan tugas itu.

Akan tetapi, kondisi kaum ibu saat ini mulai bergeser. Bila pada masa silam kaum ibu lebih banyak berada di rumah dan mengasuh anak-anak, sehingga lahirlah pemuda-pemuda pejuang dan orang-orang besar memimpin bangsa kini tidak lagi demikian. Seiring dengan laju perkembangan zaman, kaum perempuan tidak lagi berdiam di rumah, melainkan ikut aktif berkiprah dalam dunia kerja.

Fenomena ini tampaknya tak dapat dihindari. Dengan semakin banyaknya perempuan yang memiliki keahlian atau profesionalisme yang tinggi, menuntut aktualisasi mereka melalui bekerja di luar sektor domestik (rumah). Perempuan yang

\footnotetext{
${ }^{27}$ Syamsu al-Din abi 'Abdillah Muhammad bin Qayyim al-Jauziyah, Tuhfat al-Maudūd bi Akhkām al-Maudūd(t.tp: MaktabahDāral-Bayān, t.th), h. 136.

${ }^{28}$ Wahjoetomo, Perguruan Tinggi Pesantren, Pendidikan Alternative Masa Depan (Ttc; Jakarta: Gema Insani Pres,1997), h. 35.

${ }^{29}$ Abd.al-Rahman al-Nahlawi, Usūl al-tarbiyah al-Islāmiyah wa Asalibihā (Damsyik: Dār al-fikr, 1979), h. 363.
} 
mengenyam kesarjanaan di bidang kedokteran, ekonomi atau di bidang apa saja, tentu mendambakan bekerja pada bidangnya. Meskipun telah menjadi seorang istri atau ibu, dan semua kebutuhan keluarga tercukupi, mereka masih merasa kurang dihargai, perbedaannya jika dilarang bekerja pada sektor publik dan diharuskan hanya sebagai ibu rumah tangga secara penuh.

Dengan demikian, bila perempuan terpaksa ikut bekerja di luar rumah, maka ia harus dapat menjaga keseimbangan dan keharmonisan rumah tangganya. Rumah tangganya tidak boleh goyah, karena ia harus tetap memprioritaskan keluarga. Sehingga anak tidak merasa diabaikan,mereka masih merasa mendapatkan perlindungan, kasih sayang, dan kemesraan orang tua, sehingga anak tetap mendapatkan haknya sesuai dengan ajaran Islam.

2) Fase akhir masa kanak-kanak

Anak pada 6-7 tahun pertumbuhan fisiknya tergolong cepat, badannya bertambah tinggi, meski beratnya berkurang sehingga ia lebih tinggi dan kurus dari masa-masa sebelumnya, rata-rata setiap tahun tinggi anak bertambah 5-6 cm., sampai anak berusia 10 tahun. ${ }^{30}$ Pada periode ini daya tahan tubuh sangat baik, kesungguhan dan geraknya makin bertambah sehingga ia mampu memanjat pohon, berlari dan bermain yang membutuhkan gerak, sedikit sekali ia merasa lelah. Anak mampu bekerja yang sifatnya bergerak berjam-jam lamanya seperti bermain bola yang membuat ototototnya semakin kuat. ${ }^{31}$

Menurut Zakiah Daradjat, pertumbuhan otot-otot sudah terjadi sehingga anak sudah cukup kuat, dan sudah mampu melakukan gerak ruku' dan sujud secara mantap.Pada umur ini anak sudah dapat dilatih untuk berwudhu dan shalat, karena kemampuan anggota wudhunya dan gerakan shalat sudah dapat dilakukan menurut petunjuk yang diberikan kepadanya. ${ }^{32}$

\section{METODOLOGI PENELITIAN}

Jenis penelitian ini adalah kualitatif deskriptif pada lokasi di Desa Tamalate Kecamatan Galesong Utara Kabupaten Takalar. Fokus penelitian adalah perilaku nelayan dalam lingkungan keluarga terhadap pendidikan anak. Pendekatan yang digunakan peneliti dalam penelitian ini adalah pendekatan fenomenologis. Sumber data dalam penelitian ini adalah orang tua nelayan, anak nelayan. punggawa, sawi atau buruh nelayan. Pengumpulan data dilakukan dengan metode observasi, wawancara, dan dokumentasi dengan instrumen pedoman observasi, pedoman wawancara dan alat-alat dokumen seperti kamera dan lain-lain. Data yang terkumpulkan dianalisis dengan cara reduksi data, penyajian data, dan verifikasi data. Untuk mendapatkan data yang absah, maka diuji dengan cara ketekunan pengamatan, trianggulasi, dan Pengecekan anggota (member checks).

\section{HASIL PENELITIAN DAN PEMBAHASAN}

\section{Mendidik Anak Masa Kandungan}

Keberhasilan anak dalam kehidupannya sangat berkorelasi dengan perilaku orang tua dalam mendidik anak-anaknya. Apabila perilaku atau tindakan orang tua

\footnotetext{
${ }^{30}$ F.J. Mort. Dkk, Psikologi Perkembangan (Ttc; Yogyakarta: Gajah Mada University Press, 1988), h. 162.

${ }^{31}$ F.J. Mort. Dkk, Psikologi Perkembangan,1988., h. 162.

${ }^{32}$ Zakiah Daradjat, Pendidikan Agama Dalam Keluarga, Bagi Anak Usia 6-12 Tahun dalam Pendidikan Agama dalam Keluarga (Ttc; Bandung: Remaja Rosda Karya, 1996), h. 102.
} 
berlangsung baik dalam keluarga, maka anak akan tumbuh menjadi anak yang baik. Demikian sebaliknya, apabila anak mendapat perlakuan yang tidak baik, maka anak tersebut akan tumbuh menjadi anak yang yang tidak baik. Dengan demikian, perlakuan orang tua akan sangat menentukan masa depan pendidikan anak-anak mereka.

Pada dasarnya masyarakat nelayan memiliki ciri dan perilaku yang unik dan berbeda dengan keluarga atau masyarakat lain pada umumnnya. Keunikan nelayan terutama dalam hal mendidik anak tergambar dari perilaku atau sikap mereka dalam mendidik anak-anak mereka.

Pada umummnya keluarga nelayan tidak tamat sekolah dasar, sehingga mereka memiliki perilaku yang unik dalam mendidik anak-anak mereka, yang banyak bernuansa mitos yang berlaku dalam keluarga nelayan tersebut. Selanjutnya bagaimana gambaran tingkat pendidikan keluarga nelayan, maka selanjutnya dapat di ketahui dari hasil wawancara tersebut di bahwah ini.

Sehubungan dengan pernyataan tersebut di atas, salah seorang nelayan menuturkan bahwa:

Benar pak, pekerjaan saya nelayan. Saya lima bersaudara tiga laki-laki dan dua perempuan. Saya dengan saudara-saudara saya tidak ada yang tamat sekolah Dasar. Antekanmma carata lasikolah punna manna tani tankerea Tania. Jadi, saya dengan saudaraku yang laki-laki jarang tinggal di darat, karena saya terus mencari ikan di laut agar ada yang bisa di makan keluarga. ${ }^{33}$

Sehubungan dengan data tersebut di atas, juga salah seorang informan menuturkan hal yang sama, bahwa:

Saya pak dari kecil ikut membantu ayah di laut. Oleh karena itulah pak, saya tidak sempat melanjutkan sekolah. Tapi, sebenarnya saya mauji sekolah, tapi nakana bapakku siagan agan-aganku, teamako maei sikolah. Untuk apa? Kan! Ujung-ujunna doe tonji antu nassikolah taua. ${ }^{34}$

Dari hasil wawancara tersebut di atas, dapat di ketahui pada umumnya orang tua nelayan tidak tamat sekolah dasar, sehingga hal ini menurut pendapat peneliti berkorelaborasi dengan sikap atau perilaku orang tua dalam mendidik anak-anak mereka. Perilaku nelayan dapat diketahui dari tindakan atau aktifitas nelayan dalam kehidupan sehari-hari, yang teraktualisasikan dalam bentuk perbuatan yang ditimbulkan karena adanya faktor internal dan eksternal atau pengaruh dari luar.

Untuk mengetahui bagaimana perilaku keluarga nelayan dalam mendidik anak dalam keluarga terutama masa kandungan anak, maka selanjuntya dapat dilihat pada hasil wawancara berikut ini:

Ya, benar pak, keluarga kami melakukan ritual-ritual keagamaan (Islam), pada usia tujuh bulan, yang dalam bahasa Makassar disebut appassili. Hal ini kami lakukan dengan maksud supaya anak kami lahir dengan selamat dan juga dengan harapan agar anak ketika besar bisa menjadi anak yang baik, dan selamat dunia akherat. $^{35}$

Berdasarkan hasil penelitian tersebut di atas, maka dapat diketahui, bahwa keluarga nelayan di Desa Tamalate, telah mendidik anak-anak mereka sejak masih dalam kandungan ibu. Hal ini dilakukan melalui acara passili dengan motif agar anak ketika lahir bisa tumbuh sesuai harapan orang tua. Bahkan tidak hanya itu, berbagai

\footnotetext{
${ }^{33}$ Bauru Dg. Nyikko, Wawancara Pada Tanggal 25 September 2017 di Dusun Tamalate.

${ }^{34}$ Dg. Bidolo, Buruh Nelayan, Wawancara Pada Tanggal 21 September 2017 Di Dusun Soreang Desa Tamalate.

${ }^{35}$ Dg. Kanang, Istri nelayang. Wawancara, pada Tanggal 7 Maret, 2017 di Desa Tamalate.
} 


\section{Perilaku Nelayan Dalam Lingkungan Keluarga Terhadap Pendidikan Anak...}

perilaku telah ditunjukkan orang tua nelayan dalam mendidik anak-anak mereka termasuk merancang nama yang baik untuk anak setelah lahir. Untuk mengetahui hal ini salah seorang informan menuturkan bahwa:

Ya, saya punya harapan yang besar nanti ketika anak saya lahir di dunia. Oleh karena itu, sebelum anak saya lahir, saya telah merancang nama yang baik. Artinya saya sudah memutuskan secara bersama dengan suami saya nama yang baik untuk anak, dan biasanya nama kakeknya atau neneknya yang diambil. ${ }^{36}$

Dengan demikian, keluarga nelayan dalam mendidik anak-anak mereka, telah melakukan acara appassili dan juga telah merancang nama- nama yang baik untuk anakanaknya menjelang tujuh bulan masa hamil. Hal ini dilakukan selain bertujuan agar anak lahir dengan selamat sesuai dengan haparan orang tua nelayan, yang pada umumnya menginginkan agar anaknya bisa mewarisi pekerjaan ayahnya sebagai nelayan yang berani dan kuat.

Berkaitan dengan pernyataan tersebut di atas salah seorang responden menuturkan bahwa:

Semua bentuk didikan yang dilakukan dalam rumah tangga kami pak termasuk kegiatan appasili menjelang masa hamil istri saya, dan merancang nama yang baik sebelum anak saya lahir bertujuan agar anak-anak kami bisa menjadi anak yang baik ketika besar, dan juga agar anakku bisa mewarisi pekerjaan ayahnya sebagai nelayan yang tangguh kelak. Bagi kami pak hanya lautlah yang menjadi harapan kami satu-satunya. ${ }^{37}$

Dengan demikian, berdasarkan hasil wawancara tersebut di atas, maka dapat diketahui bahwa semua kegiatan yang dilakukan dalam rumah tangga nelayan terhadap pendidikan anak-anak mereka adalah agar anak ketika besar bisa menjadi anak yang berhasil sesuai harapan keluarga nelayan yang pada umumnya menginginkan anaknya bisa mewarisi pekerjaan ayahnya sebagai nelayan yang tangguh seperti ayahnya. Bagi nelayan laut menjadi harapan satu-satunya dan menjadi tumpuan hidup mereka. Bagi nelayan tidak ada sumber-sumber lain yang dianggap paling menjanjikan masa depan anak selain masalah melaut.

Mendidik anak menurut peneliti tidak hanya dilakukan pada saat anak lahir ke dunia, tetapi bisa dilakukan pada saat bayi masih dalam kandungan ibu. Dalam masalah ini, agama islam pun telah membenarkan keyakinan tersebut. Dengan demikian kegiatan appasili yang dilakukan oleh orang tua nelayan pada saat ibu sedang hamil, sesuai dengan ajaran agama Islam, walaupun sesungguhnya dalam pelaksanaannya ada yang kontradiktif dengan ajaran Islam.

Menurut kepercayaan masyarakat nelayan, bahwa ketika perempuan sedang hamil, maka seorang ibu yang hamil dilarang melakukan hal-hal yang tidak baik seperti membunuh, memotong jari-jari kepiting. Karena hal ini diyakini bisa menyebabkan anak lahir dalam keadaan cacat. Oleh karena itu, semua keluarga diharuskan berbuat baik atau tidak merusak. Hal ini pun telah diajarkan dalam Islam. Seperti misalnya ketika ibu sedang hamil, maka sangat dianjurkan ibu yang sedang hamil dan bahkan suaminya untuk rajin membaca kitab suci Al-Qur,an, karena hal ini dapat berpengaruh positif. pada bayi dalam kandungan ibu yang sedang hamil. Demikian sebaliknya, ketika isrtri sedang hamil, maka anggota keluarga dilarang melakukan hal-hal yang bertentangan dengan agama, karena hal ini diyakini dapat berpengaruh pada bayi akan lahir.

\footnotetext{
${ }^{36}$ Dg. Ngintang Baya, Istri nelayan Wawancara, di Desa Tamalate pada Tanggal 7 Maret, 2017

${ }^{37}$ Dg. Kenna, istri nelayan, Wawancara pada tanggal 25 oktober 2017 di Desa Tamalate.
} 


\section{b. Mendidik Anak Masa Kelahiran.}

Perilaku keluarga nelayan dalam mendidik anak tampak dari aktivitas mereka. Secara realitas perilaku nelayan dalam mendidik anak dibentuk oleh lingkungan dan budaya yang berlaku di lingkungan tersebut. Pada masa kelahiran anak nelayan, keluarga sudah mulai menentukan hari yang baik bagi anaknya untuk pelaksanaan akikah bagi anak-anak mereka. Hal ini dilakukan secara turun temurun, bahkan termasuk ketika para nelayan hendak melaut ia sangat hati-hati dalam menentukan hari yang baik. Salah memilih hari yang baik menurut kepercayaannya dapat mendatangkan kehidupan sial bagi keluarga mereka.

Keluarga nelayan menjelang kelahiran anaknya menyiapkan berbagai macam kesiapan yang dilakukan, baik itu berstatus "sawi" maupun "punggawa" mulai dari kesiapan biaya persalinan, pakaiannya. Perilaku ini dilakukan tidak lain adalah didorong oleh adanya rasa kebahagiaan, kegembiraan yang mendalam dan tanggung jawab atas kehadiran anak sebagai anggota keluarga yang baru. Tindakan yang dilakukan menjelang persalinan membawa ke rumah sakit atau Puskesmas bahkan menghadirkan sanro dalam istilah bahasa Makassar (dukun beranak) untuk membantu proses persalinan dan biaya persalinan ditanggung keluarga terutama orang tua sendiri.

Selanjunya menjelang kelahiran anak, mereka telah mengazankan dan melakukan iqamat sebagaimana sunnah nabi, hal ini telah diperkuat oleh salah seorang Informan yaitu sebagai berikut:

Ya, Pak waktu anak saya lahir, dan sudah memakan waktu tujuh hari, kami telah melakukan ritual-ritual keagamaan dan ini telah dilakukan orang tua saya secara turun temurun. Yang saya maksudkan pak bahwa keluarga nelayan secara umum melakukan adzan dan iqamat yang diperdengarkan saat bayi lahir. Ini kami lakukan dengan harapan ketika anak kami besar bisa menjadi anak yang patuh pada orang tua, dan agar anak menjadi anak yang saleh, serta bisa menjadi pelaut yang kuat dan berani seperti bapaknya. ${ }^{38}$

Dari hasil wawancara tersebut di atas, dapat diapresiasi bahwa keluarga nelayan telah melaksanakan akikah sesuai sunah Nabi besar Muhammad saw, dan juga sesuai adat yang berlaku pada keluarga nelayan di Desa Tamalate. Melaksanakan akikah bagi bayi adalah anjuran yang disunnahkan menurut jumhur imam dan ahli fikih. Kegiatan akikah ini diyakini oleh masyarakat nelayan dapat menambah nilai keakraban sesama manusia, selain itu cinta, dan ikatan sosial antara keluarga, kerabat, dan tetangga, karena hadirnya mereka pada acara akikah untuk bergembira dengan lahirnya sang bayi.

Relevan dengan data tersebut di atas, seorang informan menuturkan bahwa:

Menjelang kelahiran anak saya yang kedua, saya juga mengadakan akikah pada hari yang ke tujuh dengan harapan anak saya kelak akan menjadi anak yang baik sesuai harapan kami/orang tua. Sudah menjadi tradisi bagi keluarga secara turun temurun pada saat anak kami lahir harus diakikahkan pak, walaupun kami dalam kekurangan uang. Pada hal kalau dipikir-pikir pak pendapatan suami saya hanya sedikit saja, karena hanya menunggu belas kasihan dari juragan. ${ }^{39}$

Dengan demikian, keluaraga nelayan di desa Tamalate telah melakukan akikah sesuai sunnah rasulullah saw. Masyarakat nelayan di Desa Tamalate pada umumnnya Tamalate.

${ }^{38}$ Syamsuddin Dg. Tayang, Nelayan Wawancara pada Tanggal 25 September 2017 di Desa

${ }^{39} \mathrm{Dg}$. Bidolo, buruh nelayan. Wawancara pada Tanggal 9 Maret di Dusun Soreang Desa Tamalate. 
melakukan akikah pada saat anaknya lahir. Hal ini dilakukan selain sebagai bentuk kesukuran atas lahirnya anak, juga diyakini bahwa hal ini bisa menjadi asbab anak selamat di dunia dan akherat.

Dalam melakukan akikah pada keluarga nelayan di Desa Tamalate dilakukan berdasarkan pesan-pesan agama dan secara budaya sebagaimana kebiasaan yang sering dilakukan oleh para keluarga nelayan misalnya para keluarga mereka memberikan doa khusus dari keluarga mereka.

Sehubungan dengan pernyataan tersebut di atas, maka salah seorang anggota keluarna nelayan menuturkan bahwa:

Pada saat anak saya dilahirkan, hampir semua keluarga datang termasuk tetangga datang ke rumah dan memberikan barakka dengan cara meletakkan sesuatu benda di kepala anak, kemudian mengulas-ngulas kepala anak, kemudian selanjunya sang keluarga berkata. Lompoko naik nupanran mange abbisean, kamma ton anne neneknu tena namalla ribomban lomppoa. Kamanna kere-kere mae punna ajjala nasare, bomban tamparan bomman pakkuburantonji. ${ }^{40}$

Dengan demikian, berdasarkan hasil wawancara tersebut dapat digambarkan bagaimana sikap orang tua nelayan dalam mendidik anak-anak mereka. Dalam kondisi ekonomi yang serba pas pasan mereka tetap melakukan ritual-ritual keagamaan sebagai salah satu bukti kesukuran mereka atas lahirnya seorang bayi di tengah-tengah keluarga mereka. Orang tua nelayan atas kelahiran anaknya hanya berharap agar kelak bisa mewarisi pekerjaannya sebagai nelayan. Bagi mereka pekerjaan nelayan adalah hal cukup baik, walaupun juga mereka menyadari bahwa pekerjaan nelayan sangat berat, dan bahkan menurut persepsi peneliti orang tua nelayan dengan berat hati mewariskan pekerjaan ayahnya sebagai nelayan yang kuat, namun karena faktor kondisi yang mengharuskan demikian sehingga satu-satunya pendidikan yang diwariskan kepada anak hanyalah menjadi nelayan yang tangguh seperti ayahnya.

Terkait masalah akikah tidak semua orang tua melakukan berdasarkan sunah nabi, hal ini dapat dilihat dari ritual-ritual yang mereka lakukan. Ada orang tua yang hanya melakukan akikah apa adanya sesuai kondisi ekonomi mereka. Orang tua seperti ini hanya sekedar memberikan nama anaknya melalui dukun beranak atau sanro dengan cara mengundang sanak keluarga dan tetangga kemudian meresmikan nama bayi yang baru lahir. Dalam pelaksanaan akikah yang seperti ini orang tua harus mengadakan beberapa persyaratan sesuai permintaan sang dukun, antara lain : Dupa dan kemenyan, Gula pasir, Kelapa muda, Dupa, Lilin. Semua persyaratan tersebut mutlak harus ada, karena hal itu diyakini oleh orang tua nelayan sebagai hal yang sangat penting sehubungan dengan kelahiran anak.

Apa hikmah dibalik semua aktivitas nelayan seperti tersebut di atas, untuk mengetahui hal ini peneliti berikut dipaparkan hikmah dibalik kegiatan tersebut. Perlunya dupa, kemenyam dan gula dalam kegiatan tersebut dimaksudkan agar kelak anak mendapat keberkahan dari sang pencipta, dalam hal ini, hidupnya tidak akan dapat sial atau berjalan dengan baik. Kalau tidak ada kemenyan dan dupa, maka roh-roh jahat dapat merasuki jiwa anak yang baru lahir. Demikian kepercayaan keluarga nelayan tersebut. Tamalate.

${ }^{40}$ Dg. Rate, Nelayan, Wawancara pada Tanggal 20 November 2017 di Dusun Soreang Desa 


\section{c. Pendidikan Keimanan}

Pada dasarnya orang tua nelayan sangat kurang sekali waktunya untuk membimbing atau mngarahkan anaknya melaksanakan shalat lima waktu. Hal ini sesuai dengan hasil wawancara dari salah seorang nelayan, yaitu sebagai berikut:

Sebagai orang tua, saya tetap merasa prihatin kalau anak saya tidak shalat. Tapi apa mau dibuat, pak. Karena saya jaran di rumah. Sebagai nelayan saya lebih banyak menghabiskan waktuku di laut. Jadi, kalau kebetulan saya ada dirumah, maka saya tetap meminta dia shalat di Masjid. ${ }^{41}$

Dengan demikian orang tua nelayan tetap prihatin kalau anak- anaknya tidak shalat, sebagaimana orang tua yang lain pada umumnnya. Namun karena faktor waktu yang sangat sedikit sehingga orang tua hanya menyerahkan penuh pendidikan agama anak-anaknya kepada para ustas dan ustdza.

Sehubungan dengan hal di atas, maka selanjutnya dikemukan hal yang sama.

Sebagai nelayan boleh dikatakan bahwa waktu dalam mendidik anak pada khususnya di rumah sangatlah kurang. Jadi, pada hanya waktu-waktu tertentu saja saya punya waktu meminta anak saya melakukan shalat, yaitu di waktu saya pulang mencari ikan di lautan.

Dari dua pernyataan tersebut di atas, maka dapat ditelusuri, bahwa ternyata orang tua nelayan berkeinginan besar dalam mendidik anak-anak mereka, termasuk masalah ibadah-ibadah khusus.

Selain apa yang telah diapresiasi penulis tersebut di atas, maka hal lain yang menjadi masalah keluarga nelayan dalam pendidikan keimanan adalah karena mereka tidak bisa memberikan contoh yang baik kepada para anak-anak mereka. Hal ini telah diperkuat oleh salah seorang tokoh agama, yaitu sebagai berikut:

Ya, saya heran bagi keluarga nelayan di Desa Tamlate, karena mereka marah dan juga memerintahkan anaknya untuk shalat di masjid sementara itu pak bapaknya dan ibunya tidak bisa menjadi teladan bagi anaknya. Maksud saya pak bapaknya tidak mau shalat di Masjid, dan bahkan di rumahmnya pun mereka tidak mau shalat. Mereka hanya disibukkan oleh pekerjaan, tanpa mau peduli akan kewajibannya sebagai seorang orang tua. ${ }^{42}$

Dengan demikian dari hasil wawancara tersebut di atas, dapat ditelusuri bahwa pada dasarya keluarga nelayan tidak bisa bisa memberikan pendidikan keteladan terutama berkaitan pendidikan keimanan. Orang tua nelayan hanya biasa memerintahkan anaknya tanpa memberikan contoh lebih awal. Sebagai orang tua menurur pendapat peneliti agar ia sukseks dalam mendidik anak-anak mereka, maka ia perlu melakukan lebih awal atau ia perlu menjadi contoh bagi anak-anak mereka. Karena sangat mustahil anak akan bisa melakukan apa yang diinginkan orang tua, karena dia sendiri tidak bisa melakukan. Sama halnya dengan masalah merokok ia memerintahkan kepada anak-anak mereka agat tidak merokok, tapi orang tua sendiri kuat merokok atau tidak mampu memberikan keteladan. Hal ini seperti disampaikan oleh informan yang sama seperti tersebut di atas.

Orang tua nelayan pak sangat mengingingkan agar anak-anaknya berhenti merokok, padahal orang tuanya sendiri kuat merokok. Bahkan ada orang tua nelayan tiada jam tanpa merokok. Orang tua yang seperti ini tidak akan pernah

\footnotetext{
${ }^{41}$ Dg. Sila, nelayan, wawancara pada tanggal 25 April di Desa Tamalate..

42. Dg. Mone, tokoh agama, Wawancara pada Tanggal 3 September 2017 di Dusun Bontotannga Deasa Tamalate
} 


\section{Perilaku Nelayan Dalam Lingkungan Keluarga Terhadap Pendidikan Anak...}

berhasil untuk melarang anaknya untuk tidak merokok, karena oarang tuanya sendiri adalah pelaku utama.

Menurut pendapat peneliti bahwa harapan orang tua untuk menjadikan anaknya lebih baik hanya sekedar impian saja. Bukankah dalam pendidikan Islam ditekankan bahwa orang tua harus mampu melakukan pendidikan keteladan bagi anak-anak mereka. Jika orang tua bisa menjadi teladan yang baik bagi anak-anak mereka, maka dipastikan orang tua akan mampu mengarkan anaknya sesuai dengan keinginannya.

Masalah ekonomi telah menjadikan keluarga nelayan berprilaku negatif dalam mendidik anak-anak mereka. Karena berdasarkan temuan peneliti dilapangan, bahwa pada umumnya mereka memiliki keinginan yang kuat, namun karena faktor kebutuhan pertama yang lebih mendesak, sehingga terpaksa ia mengabaikan pendidikan anak-anak mereka termasuk dalam mengaplikasikan kewajibannya sebagai seorang muslim. Untuk keluar dari permasalahan ini, maka item pertama yang perlu dibenahi adalah masalah ekonomi. Oleh karena itu, peran pemerintah sangat dibutuhkan dalam mengatasi hal tersebut.

\section{d. Masalah Akhlak}

Sejak awal kehidupan manusia sudah mengenal kata akhlak walaupun dalam istilah yang berbeda. Dulu orang tua kita sangat tegas mempertahankan bagaimana bertutur kata yang baik, bagaimana jika lewat di depan orang tua atau orang banyak. Perilaku ini mulai tanpak pudar di tengah-tengah masyarakat moderen. Hal ini sebagai buah negatif dari benturan budaya dan adat yang lahir dari berbagai belahan dunia.

Selanjutnya untuk mengetahui bagaimana sikap orang tua dalam penanaman nilai-nilai akhlak pada anak atau generasi, maka dapat di lihat pada uraian berikut ini:

Sikap orang tua dalam pendidikan moralitas, bisa dikatakan tergolong cukup bagus. Karena orang tua telah menanamkan perilaku yang baik kepada para anak sejak kecil, misalnya tentang cara lewat di depan oarang tua, cara makan yang sopan, cara bertutur kata, cara menyapa dan cara menghargai orang lain.

Untuk mengetahui hal tersebut maka selanjutnya dapat dilihat pada hasil wawancara tersebut di bawah ini.

Ya, memang benar, kami dari keluarga nelayan masih menjunjung tinggi adat makassar. Seorang anak yang tidak patuh pada orang tua akan dipandang hina dalam pandangan masyarakat. Oleh karena itulah, anak-anak sejak kecil telah dibekali pengetahuan bagaimana ketika lewat di depan orang tua. Anak tidak boleh lewat bgitu saja, tanpa tabe dalam bahasa makassar. Apabila anak lewat tanpa tabe, maka ia dimarahi oleh orang tua mereka. ${ }^{43}$

Berkaitan dengan data tersebut di atas, maka salah seorang anak nelayan memperkuat penuturan tersebut di atas, bahwa:

Saya sangat takut lewat di depan orang tua saya tanpa tabe. Kalau kita lewat di depan orang tua, tanpa tabe, maka saya langsung ditegur dan disebut sebagai

\footnotetext{
${ }^{43}$ Istri nelayan, Wawancara pada Tanggal 25 April, 2017 di Desa Tamalate.. Tabe adalah bahasa Makassar. Tabe bermakna sopan, ketika lewat di depan orang, apalagi yang lebih tua dari kita, maka harus tabe kalau mau lewat, sebab kalau tidak dianggap kurang ngajar. Kata tabe ini masih di junjung tinggi oleh suku Makassar sampai sekarang ini. Dan kata tabe masih tetap dipelihara oleh suku Makassar agar budaya lokal tetap terjaga dengan baik. Kata tabe menurut peneliti sesungguhnya sangat relevan dengan nilai-nilai Islam yang telah menjunjung akhlak seperti yang dicontohkan Rasulullah Muhhammad saw.
} 
anak yang kurang ngajar. Jadi, orang tua saya selalu mengingatkan agar saya mematuhi segala peraturan dalam rumah tangga. ${ }^{44}$

Dari hasil wawancara tersebut di atas, maka peneliti dapat mendeskripsikan bahwa pada umummnya anak- anak di Desa Tamalate mendapat pendidikan akhlak dari orang tua. Pendidikan seperti ini telah dilakukan orang nenek moyang mereka secara turun temurun. Pendidikan moral seperti ini pula telah dijaga dan dipelihara oleh para orang tua. Hal ini dilakukan demi menjaga nilai-nilai yang telah dijunjung tinggi dari dulu oleh orang tua. Bagi orang makassar mematahui nilai-nilai yang telah disepakati adalah suatu keormatan yang terterbatas nilainya. Demikian sebaliknya melanggar norma-norma yang telah disepakati sebagai sebuah nilai berarti sama dengan menginjak-nginjak ajaran agama Islam, karena semua itu telah diadopsi dari ajaran Islam.

Anak sesuai fitrahny selalu ingin bergaul di luar lingungan keluarga. Kondisi ini menjadi hal yang negatif bagi perkembangan anak nelayan di Desa Tamalate. Sehubungan dengan hal ini, maka salah seorang anak nelayan mendeskripsikan bahwa:

Ya, benar. Saya selalu bergaul dengan teman-temanku, apalagi kalau lagi tidak melaut pak saya terkadang tidak pulang-pulang rumah. Jadi, lebih banyak waktu saya di luar rumah bersama dengan teman-teman. Orang tua saya selalu marah kalau selalu bermalam di rumah teman-temanku. ${ }^{45}$

Dengan demikian, berdasarkan hasil wawancara tersebut di atas, maka dapat diketahui bahwa anak- anak nelayan di Desa Tamalate banyak bergaul di luar rumah, sehingga hal ini bisa menjadi pemicu dalam pembentukan moral anak nelayan di Desa Tamalate. Bagaimana pun baiknya pendidikan dalam lingkungan keluarga kalau anakanak banyak bergaul di luar rumah, maka hal itu bisa menjadi ancaman bagi pendidikan masa depan anak-anak. Hal ini sudah dapat disaksikan dimana-mana. Anak pada usia dini telah dinikahkan, karena hamil di luar nikah. Oleh karena itu, maka orang hendahnya menjaga dan memelihara anak-anak mereka agar tidak terjeumus dalam perbuatan-perbuatan yang tidak sesuai dengan norma masyaraka, norma agama, dan juga norma hukum. Apabila anak terjerumus dalam perbuatan hitam seperti ini berart ia telah mencoreng nama baik keluarga, merusak nama kampung, agama dan termasuk mencederai nama pancasila sebagai dasar agama bangsa Indonesia.

Dari beberapa deskripsi tersebut di atas, maka berati pendidikan akhlak dalam rumah seperti pndidikan kesopanan telah menujukkan hal yang positif dalam lingkungan rumah tangga, namun karena faktor lingkungan pergaulan yang semakin tidak sehat, sehingga pendidikan akhlak anak-anak mulai tidak mencerminkan nilainilai seperti yang diajarkan oleh agama Islam. Bukankan Rasululah Muhammad saw di utus ke di dunia ini adalah untuk memperbaiki akhlak manusia.

\section{e. Mendidik Anak melaut sejak dini}

Dalam mendidik anak orang tua nelayan pada khususnya di Desa Tamalate memiliki perilaku yang unik, utamanya dalam masalah mendidik anak di laut. Dengan demikian, masyarakat nelayan memiliki ciri khas tersendiri dalam mendidik anak. Pendidikan yang diberikan kepada anak-anak mereka lebih banyak berlangsung secara natural. Selain hal tersebut, waktu yang mereka gunakan dalam mendidik anak-anak mereka sangat kurang, karena mereka lebih banyak menghabiskan waktunya di laut untuk mencari ikan. Seiring dengan perjalanan waktu yang panjang mereka

\footnotetext{
${ }^{44}$ Bakri, anak nelayan Wawancara pada tanggal 25 April 2017 di Desa Tamalate

${ }^{45}$ Risal, Anak nelayan. Wawancara pada tanggal 27 april 2017 di Desa Tamalate
} 
membesarkan anak-anak mereka dengan berbagai cara tanpa harus di didik secara sistematis.

Relevan dengan pernyataan tersebut di atas, maka salah seorang informan menuturkan bahwa:

Ya, pak pekerjaan saya adalah sebagai nelayan. Hal ini saya lakukan sejak kecil. Orang tua saya selalu melibatkan aku mencari ikan di lautan untuk mencari ikan. Waktu saya di laut bersama keluarga lebih banyak dibandingkan di daratan. Oleh karena itulah, pak saya sangat terampil dalam masalah melaut. ${ }^{46}$

Relevan dengan data tersebut di atas, maka salah seorang informan menuturkan hal yang sama, bahwa:

Sejak kecil pak saya senang melaut. Oleh karena itulah pada umur dubelas tahun saya jarang tinggal di darat. Saya lebih banyak menghabiskan waktu di laut untuk mencari ikan bersama bapak saya. Tapi sekarang ini, orang tua tidak ikut melaut lagi karena sudah tua. Jadi, sayalah yang melanjutkan pekerjaan bapak saya yang memang sejak kecil telah di tanamkan, kepada saya.

Dari wawancara tersebut di atas, maka peneliti dapat mendeskripsikan bahwa pada umumnnya masyarakat nelayan lebih banyak menghabiskan waktunya di laut. Oleh karena itu, anak-anak nelayan bisa dikatakan bahwa mereka telah dibesarkan di lautan oleh orang tua mereka, dan diselah-selah kesibukan itulah mereka diajar berbagai pengetahuan tentang bagaimana menjadi seorang pelaut yang tangguh dalam berlayar seperti orang tua merka.

Sehubungan dengan pernyataan tersebut di atas, maka salah seorang informan menuturkan pengalaman belajarnya sejak kecil di laut, yaitu:

Waktu saya masih berumur sepuluh tahun, saya sudah mulai ikut mendampingi ayah di laut mencari ikan. Di lautan itulah pak bapak saya pertama kali mengajarkan bagaimana mendayung dengan baik, bagaimana membaca tandatanda laut terutama ketika ombak besar, dan sekaligus memperhatikan bapak saya dengan cermat dalam menggunakan kapal dengan gagah berani, walaupun ombak sangat besar. ${ }^{48}$

Dari hasil wawancara tersebut di atas, maka peneliti dapat mendeskripsikan bahwa orang tua nelayan telah mewariskan ilmunya kepada anak-anaknya dengan cara ayah melibatkan secara langsung anak-anak mereka di laut, dan anak melihat secara langsung aktivitas ayahnya melalui penglihatan secara langsung oleh anak-anak mereka sehingga, anak bisa melakukan cara melaut yang baik, dalam hal ini anak-anak nelayan pada umumnya terampil mengendalikan kapal termasuk ketika kapal sedang berhadapan dengan ombak yang besar.

Sehubungan dengan pernyataan tersebut di atas, maka salah seorang informan menuturkan hal yang sama, yaitu sebagai berikut:

Benar, pak! sejak umur sembilan tahun saya sudah mulai berlayar bersama orang tua saya. Adapun yang pertama-tama bapak ajarkan kepada saya adalah masalah cara memegang dayung yang benar. Setelah saya tahu, maka selanjunya saya sangat rajin melaut untuk mencari ikan. ${ }^{49}$

Dengan demikian, maka dapat diketahui bahwa, semua tindakan atau aktivitas masyarakat nelayan di laut adalah tentu sangat bermuara kepada anaknya yang melihat

\footnotetext{
${ }^{46}$ Bauru Dg, Gau, Nelayan. Wawancara, di Desa Tamalate pada Tanggal 3 September 2017

${ }^{47}$ Ahmad Dg. Boko, Wawancara di Desa Tamalate pada tanggal 3 september 2017

${ }^{48}$ Ahmad Dg. Bonto, Wawancara pada Tanggal 25 Oktober 2017 di Desa Tamalate.

${ }^{49}$ Dg. Naba. Wawancara di Desa Tamalate pada Tanggal 28 Oktober 2017.
} 
secara langsung aktivitas mereka, termasuk ketika orang tua memperbaiki kapal yang rusak, saat ia memperbaiki jaringnya, saat menangkap ikan, berhadapan dengan ombak besar, atau saat orang tua melarang anaknya melakukan sesuatu di atas kapal, karena bagi masyarakat nelayan ada banyak hal yang tidak bisa dilakukan pada saat akan berangkat di laut dan bahkan termasuk ketika sedang berlayar atau sedang mencari ikan.

Masyarakat nelayan adalah sosok pekerja berat, ia memiliki semangat yang besar karena didorong oleh semangat hidup yang kuat demi untuk masa depan anakanak mereka. Untuk menutupi kebututuhan rumah tangga pun pihak istri pun terlibat bekerja membantu suaminya untuk mempersiapkan segala kebutuhan suami pada saat akan melaut. Untuk mengetahui hal ini salah seorang istri nelayan menuturkan bahwa:

"Sebagai istri, saya terlibat membantu suamiku pada saat akan melaut. Tugas ini, saya kerjakan secara terus menerus dan saya tak pernah mengenal pasrah ini demi masa depan anak-anak saya yang masih kecil. ${ }^{50}$

Menurut pengamatan peneliti aktivitas rumah tangga nelayan ternyata dimulai sebelum shalat subuh. Mereka menyiapkan kebutuhan suami untuk di laut, kaum ibu memasak, mencuci, membersihkan rumah serta menyiapkan pakaian sekolah anak.

Seorang istri atau ibu rumah tangga yang baik sering dinilai sebagai motor penggerak keluarga apalagi di pagi hari, dari hal mengurus anak-anak ke sekolah dan juga menyiapkan keperluan suami dan juga keterampilan memasak. Walaupun kegiatan ini sering juga dibantu oleh anak-anak perempuan mereka. Namun, anak laki-laki hanya mempersiapkan keperluannya saja.

"Jika bukan waktu sekolah tugas dari anak laki-laki adalah membantu ayahnya menangkap ikan di laut. Karena itu memang pekerjaan yang mereka tangani adalah yang berkaitan dengan kenelayanan, kalau untuk anak laki-laki yang belum dapat di bawa ke laut, diberi tugas untuk membersihkan berbagai peralatan melaut seperti membersihkan jaring dari kotoran-kotoran selepas digunakan oleh bapaknya untuk menangkap ikan, atau membereskan dan membersihkan perahu setelah digunakan berlayar menangkap ikan. Dan juga membawa hasil tanggkapan ayahnya." 51

Berdasarkan hasil wawancara tersebut di atas, bahwa anak laki-laki sejak kecil diajar atau dididik oleh ayahnya. Ketika anak-anak tidak pergi melaut ia merawat perahu, memperbaiki jaring dan lain-lain sebagainya yang membuat anak - anak di desa Tamalate Kecamatan Galesong Utara Kabupaten Takalar telalu disibukkan dengan aktivitas melaut hingga melupakan pendidikan informasi tentang perkembangan teknologi zaman yang semakin maju dan moderen.

Dalam mendidik anak di rumah, para orang tua nelayan tampaknya jeli dan hatihati , karena waktunya sangat terbatas. Dalam kaitan ini, seorang informan/perempuan memberikan apresiasi bahwa:

Keluarga nelayan ( punggawa dan pemilik kapal)di Desa Tamalate juga sangat perhatian terhadap pendidikan anak-anak mereka. Bagi orang tua yang sedang belajar anak-anaknya mengaji di sore hari, ia biasa mengantar langsung anakanaknya di tempat pengajian. Dan juga anak-anak yang sementara sekolah termasuk di Taman-Kanak-Kanak orang tua nelayan sangat antusias menyiapkan

\footnotetext{
${ }^{50}$ Dg. Cinnong, Istri buruh nelayang, Wawancara pada tanggal 26 Pebruari 2017 di Dusun Bontotannga Desa Tamalate.

${ }^{51} \mathrm{Dg}$. Jai, Istri buruh nelayan, Wawancara, pada tanggal 27 Pebruari 2017 di Dusun Bontotannga Desa Tamalate
} 
segala kebutuhan anak, termasuk baju seragam sekolah, buku, pensil dan sebagainya. ${ }^{52}$

Berdasarkan hasil wawancara tersebut di atas, maka dapat ditelusuri, bahwa Keluarga nelayan di Desa Tamalate Kecamatan Galesong Utara Kabupaten Takalar juga sangat aktif dalam mengarahkan pendidikan anak..

Perilaku di atas sebagai wujud dan bentuk keprihatinan orang tua terhadap masa depan pendidikan anak-anak mereka. Namun diakui bahwa masyarakat nelayan memiliki keterbatasan dalam mengaktualisasikan tanggung jawabnya sebagai pendidik utama dalam keluarga terutama yang berkaitan pendidikan formal.

Dalam mendidik anak termasuk dalam rumah tangga nelayan diperlukan pengetahuan atau sumber daya manusia yang baik. Tanpa sumber daya manusia yang baik, maka pelaksanaan dari pendidikan tersebut tidak mungkin akan berjalan dengan baik. Bagi masyarkat nelayan sangat terkendala dengan masalah sumber daya manusia (SDM) yang rendah, karena pada umumnnya tingkat pendidikan mereka tidak tamat atau hanya lulusan sekolah dasar. Karena masyarakat nelayan, umummnya tidak tamat sekolah dasar atau tidak memiliki sumber daya manusia yang bisa diandalkan, maka ia dalam hal mendidik terkadang berperilaku keras.Dalam kaitan ini, maka salah informan menuturkan, bahwa:

Ya, pak profesi saya sebagai nelayan. Terkait masalah mendidik anak, saya sangat keras pak dan saya tidak segan-segan bertindank tegas. Kalau perlu saya pukul anakku, kalau tidak mau mendengarkan permintaan saya. Pak. ${ }^{53}$

Sehubungan dengan pernyataan tersebut di atas, maka jelaslah bahwa sikap masyarakat nelayan dalam mendidik anak dalam rumah tangga tampak keras. Apalagi ketika sedang melaut, maka perilaku mereka dalam mendidik terkadang tidak rasional.

Sehubungan dengan data tersebut di atas, maka salah seorang informan menuturkan, bahwa:

Setiap saya pergi mendampingi ayah mencari ikan di laut, saya selalu di marahmarahi, dan bahkan terkadang saya dibentak-bentak. Saya dianggap anak yang malas, tidak becus. Oleh karena itulah pak, saya malas lagi mendampingi ayahku melaut. ${ }^{54}$

Relevan dengan data tersebut salah satu anak nelayan menutrurkan bahwa:

Saya tiga bersaudara dan semuanya laki-laki. Saya selalu mendampingi ayah mencari ikan di laut. Jika saya tidak mau pergi melaut atau malas, maka saya dimarahi, dan bahkan dicaci maki, dengan alasan apa yang akan dimakan atau dimanaki mau ambil uang, karena kita miskin. ${ }^{55}$

Dari deskripsi informan tersebut di atas, maka dapat ditelusuri, bahwa keluarga nelayan dalam mendidik anak-anak memang sangat disiplin (di laut) dan bahkan terkadang mereka mencaci maki anak-anak mereka kalau anak enggan mengikuti perintahnya.

Dengan demikian, berdasarkan uraian tersebut di atas, maka peneliti dapat mendeskripsikan bahwa keluarga nelayan dalam mendidik terkadang menampakkan

\footnotetext{
${ }^{52}$ Dg. Darmawati, tokoh agama, Wawancara Pada tanggal 23 Pebruari 2017 di Desa Tamalate.

${ }^{53}$ Tarawe Dg. Gassing, Nelayan. Wawancara pada Tanggal 29 Oktober 2017 di Dusun Bontotangnga Desa Tamalate.

${ }^{54}$ Dg, Nai, Nelayan Wawancara Pada Tanggal 23 Oktober 2017 di Desa Tamalate.

${ }^{55}$ Risal, Anak Nelayan, Wawancara di Desa Tamalate pada Tanggal 26 April 2017 di Desa Tamalate.
} 
perilakunya yang tidak baik. Mengapa peneliti berasumsi demikian, karena ia selalu menggunakan kekerasan dalam mendidik anak-anak mereka. Perilaku mereka dalam mendidik anak-anak tentunya sangat tidak rasional, karena pelaksanaan pendidikan yang seperti itu selain tidak rasional juga bertentangan dengan konsep pendidikan Islam. Bukankah dalam mendidik anak Islam menganjurkan agar berlangsung secara bilhikmah atau sebaliknya bukan dengan kekerasan.

Mengapa keluarga nelayan dalam mendidik anak-anak cenderung berlaku kasar. Menurut peneliti hal ini berkaitan secara psikologis dengan keluarga nelayan yang jika dilihat secara ekonomi dan kesibukan mereka dalam menutupi segala kebutuhan rumah tangga.

Pada umumnya masyarakat nelayan trampil dalam melakukan profesinya sebagai nelayan. Kecakapan mereka dalam melaut tentu sebagai buah dari didikan ayah, yang sejak kecil telah dilatih melaut oleh ayah mereka.

Sehubungan dengan data tersebut di atas, maka salah seorang informan menuturkan bahwa:

Ya, pak saya memang lahir di Desa Tamalate . Pekerjaan saya sebagai nelayan.

Pekerjaan ini memang dari kecil saya tekuni. Karena itulah, saya sudah terbiasa

dilatih sejak kecil oleh ayah dan tidak lagi takut melihat ombak. saya berharap

kelak anak saya bisa mewarisi pekerjaan sebagai pelaut yang tangguh. ${ }^{56}$.

Dari pernyataan tersebut dapat dipahami bahwa masyarakat nelayan Desa Tamalate, pada khusunya nelayan dari kecil telah dibiasakan dan dilatih oleh para orang tua mereka dengan cara anak dilibatkan langsung mencari ikan dalam waktu yang tidak jelas. Anak nelayan di Desa Tamalate tidak lagi takut melihat ombak yang besar, karena dari kecil telah dibiasakan, dilatih, oleh orang tua mereka di laut untuk mencari ikan.

Sehubungan dengan data tersebut di atas, juga salah seorang informan menjelaskan bahwa:

Bagi keluarga pelaut seperti kami pak pekerjaan melaut memang kami sudah menganggap sebagai sebuah pekerjaan yang biasa-biasa saja. Karena memang dari kecil kami telah terbiasa di laut bersama orang tua kami. ${ }^{57}$

Dengan demikian pekerjaan melaut bagi masyarakat nelayan adalah sudah menjadi hal yang biasa. Mereka tidak lagi gentar ketika berhadapan dengan ombak yang besar. Hal ini karena mereka telah terbiasa melihat secara langsung dan bahkan mereka sudah berpengalaman dari kecil melaut atas didikan ayah.

Masayarakat nelayan memiliki segudang pengetahuan dan keterampilan dalam masalah melaut, dan hal ini telah diwariskan kepada anak-anak mereka. Bahkan, keluarga nelayan mempunyai kelebihan dalam membaca dan mengetahui hal - hal yang akan mengancam jiwa mereka saat melaut.

Sehubungan dengan pernyataan peneliti tersebut di atas, maka salah seorang informan menuturkan bahwa:

Ya, pak. Pada umumnya nelayan pak mampu membaca segala tanda-tanda atau mampu membaca segala kejadian di laut. Karena kalau kita tidak tahu tentang hal-hal yang akan terjadi di laut, maka itu bisa berbahaya bagi yang bersangkutan. Oleh karena itulah, pak setiap orang tua mewariskan pengetahuan

\footnotetext{
${ }^{56}$ Arman Dg. Tompo, Wawancara Pada Tanggal 25 September di Desa Tamalate.

${ }^{57}$ Hatta Dg. Wawancara pada Tanggal 22 september 2017 di Desa Tamalate.
} 
melaut kepada anaknya dengan cara belajar secara langsung ketika anak di bawa berlayar. ${ }^{58}$

Dari pernyataan tersebut di atas, selanjunya dapat telelusuri bahwa setiap orang tua nelayan, telah mendidik dan mewariskan pengetahuan berlayar pada usia kecil, yaitu sejak umur delapan tahun. Pada usia ini anak telah diikutsertakan orang tua mereka untuk mencari ikan. Pengetahuan tentang melaut ternyata telah terbentuk dari kecil. Pengetahuan melaut diajarkan tidak secara terstruktur atau sistematis, tapi pengetahuan yang diperoleh dari orang tua mereka diperoleh secara alamiah. Pengetahuan yang diperoleh di laut sangat berbeda dengan ilmu yang diperoleh di sekolah atau di tempat formal. Di tempat formal anak-anak belajar melalui bimbingan yang teratur atau terstruktur, dan dipandu oleh guru profesional. Di laut anak-anak memperoleh pengetahuan secara alamiah, tapi dari pengembangan keterampailan mereka tanpak profesional. Artinya mereka terampil mengerjakan sesuatu terkait masalah bagaimana melaut dengan baik.

Sehubungan dengan data tersebut di atas, maka salah seorang informan menuturkan bahwa:

Orang tua kami pak, sangat terampil dalam berlayar, dia sangat memahami bagaimana mengelak atau menghindar ketika berhadapan dengan ombak yang besar. Pengetahuan seperti ini telah diwariskan kepada semua saudara saya yang laki-laki, sehingga saya pun sangat menguasai bagaimana berlayar dengan baik. $^{59}$

Dengan demikian, maka dapat diketahui dengan jelas, bahwa anak-anak nelayan seperti yang dituturkan anak nelayan tersebut di atas, bahwa pada umumnya setiap anak telah memperoleh ilmu pengetahuan tentang cara berlayar yang profesional. Pengetahuan yang baik pada anak nelayan dalam berlayar tanpaknya luar biasa. Hal ini demikian sebagai akibat dari pendidikan yang telah diberikan kepada anak-anaknya pada usia yang masih sangat mudah sekali. Anak nelayan pada usia dini, sudah mulai menunujukkan kemampuannya dan kemakhirannya dalam menggunakan kapal. Selain anak mulai menunjukkan kemampuannya juga ia sangat berani melihat ombak yang besar.

Dalam kegiatan mendidik anak-anak nelayan mendapat ilmu seperti yang diapresiasi tersebut di atas. Orang tua nelayan telah memberikan pelajaran dengan sempurna kepada anak-anaknya tentang problematika menjadi pelayar yang ulung. Ia hanya fokus kepada hal yang berkaitan dengan kelautan. Hal lain dianggap tidak terlalu menarik bagi keluarga nelayan, karena memang keluarga nelayan pada umumnya tidak memiliki keterampilan selain hanya hal-hal yang berkaitan dengan laut.

Berkaitan dengan pernyataan tersebut di atas, maka salah seorang informan menuturkan bahwa:

Benar pak! saya seorang nelayan, dan sejak kecil saya sudah terbiasa membawa perahu. Orang tua saya yang juga nelayan telah mewariskan ilmunya kepada saya. Oleh karena itulah, saya sangat terampil berlayar. Tapi untuk pekerjaan lain, saya tidak tahu apa-apa, selain masalah melaut. ${ }^{60}$

\footnotetext{
${ }^{58}$ Sutte Dg. Gau, Wawancara pada Tanggal 22 Sepetember 2017 di Desa Tamalate.

${ }^{59}$ Titto, Wawancara, pada Tanggal 23 September 2017 di Desa Tamalate

${ }^{60}$ Dg. Nassa, Nelayan, Wawancara pada Tanggal 24 Oktober, 2017 di Desa Tamalate.
} 
Dari hasil wawancara tersebut di atas, maka peneliti dapat mendeskripsikan, bahwa pada umumnya keluarga nelayan tidak memiliki keterampilan, selain hanya masalah melaut.

Dalam melaut banyak hal yang tidak bisa dilanggar dan ini telah diajarkan kepada anak-anak nelayan secara turun temurun. Misalnya pada saat perahu akan berangkat ke laut, nelayan telah melakukan persembahan-persembahan kepada dewa laut yang diyakini mampu menolak bala, dan juga bisa mendatangkan barakah. Berkaitan dengan hal ini, maka salah seorang informan menuturkan, bahwa:

Ya, pak. Sebelum kapal berangkat kira-kira dua sampai tiga hari, kami melakukan persiapan yang sifatnya memberikan sesajen kepada dewa laut, dengan cara kami mempersembahkan berupa pisang, rappo, dupa, dan kemenyam, kemudian menempatkannya di atas perahu dan dibaca-baca oleh tokoh masyarakat setempat. ${ }^{61}$.

Dengan demikian, maka dapat diketahui bahwa keluarga nelayan punya tradisi yang khas dalam melakukan aktivitas di laut. Semua aktivitas nelayan mengandung pesan-pesan yang bermakna dan memiliki tujuan. Misalnya sebelum nelayan berangkat ke laut, ia telah mempersembahkan pisang, dupa, dan membakar kemenyam dengan harapan agar usaha nelayan bisa sukseks. Bagi keluarga nelayan menentukan hari yang baik sebelum pergi melaut adalah merupakan sebuah tradisi yang berlansung turun temurun. Pada hari tertentu misalnya hari rabu dan sabtu masyarakat nelayan enggan beraktivitas dengan alasan bahwa pekerjaannya akan sial. Oleh karena itulah keluarga nelayan sangat hati-hati dalam memilih mana hari-hari yang baik dan tidak tertentu.

Berkaitan dengan data tersebut di atas, maka salah seorang informan menjelaskan bahwa:

Benar pak, bahwa masyarakat nelayan sebelum berlayar di laut, maka kami memilih hari-hari yang baik, dan bahkan kami pak pantang pergi melaut pada hari-hari tersebut. Melakukan aktivitas pada hari-hari itu pak mendatangkan sial dalam usaha kami. ${ }^{62}$

Dari dua informan tersebut di atas, maka dapat ditelusuri, bahwa pada umumnya masyarakat nelayan di Desa Tamalate meyakini bahwa pada hari tertentu seseorang tidak bisa beraktivitas, karena hal tersebut bisa menyebabkan sial dalam kehidupan kita. Dan keyakinan seperti ini ternyata telah diajarkan secara turun temurun.

Perilaku tersebut di atas, menurut analisis peneliti sangat kontradiktif dengan logika manusia. Benarkan ada hari-hari tertentu yang bisa mendatangkan sial dalam kehidupan manusia? Menurut peneliti bahwa keyakinan seperti ini justru menjadi salah satu faktor pemicu keluarga nelayan pada khususnya di desa Tamalate semakin stagnan. Artinya keyakinan seperti ini akan berdampak negatif bagi kehidupan manusia. Bagaimana caranya agar keyakinan seperti ini bisa diminamilisir atau dihilangkan? Untuk menghilangkan keyakinan yang bernafaskan mitos tersebut, maka pendidikan menjadi sebuah solusi yang paling tepat.

Sehubungan dengan data tersebut di atas, maka salah seorang informan menjelaskan, bahwa:

Bagi masyarakat nelayan masalah aturan-aturan yang berlaku di laut sangat ketat. Misalnya pak jika di atas kapal tidak boleh bicara hal-hal dianggap bisa

\footnotetext{
${ }^{61}$ Ramli Dg. Nai, Nelayan Wawancara pada Tanngal 21 Okber 2017 di Desa Tamalate.

${ }^{62}$ Suardi Dg. Ngewa, Nelayan Wawancara pada Tanngal 21 Oktober 2017 di Desa Tamalate.
} 


\section{Perilaku Nelayan Dalam Lingkungan Keluarga Terhadap Pendidikan Anak...}

mendatangngkan mudarat. Oleh kaena itu, sebelum kapal berangkat semua anggota diajar agar jangan sekali-kali melakukan hal-hal yang dilarang. ${ }^{63}$

Dari beberapa pernyataan tersebut di atas, maka dapat dideskripsikan bahwa keluarga nelayan memiliki perilaku yang khas dan banyak mengandung mitos. Perilaku ini lahir sebagai akibat dari rendahnya latar belakang pendidikan keluarga nelayan.

Keluarga nelayan di Desa Tamalate pada umumnya tidak tamat sekolah dasar. Berkaitan dengan hal tersebut, maka salah seorang informan menjelaskan bahwa:

Saya empat bersaudara dan semuanya tidak ada yang tamat sekolah dasar. Waktu saya berumur 8 tahun pak saya sudah mendampingi ayah di laut untuk mencari ikan. Kalau saya tidak ikut membantu bapak saya dengan adik-adikku, maka apa yang akan di makan. Kami berasal dari keluarga miskin. Makan saja susah, apalagi untuk sekolah. ${ }^{64}$

Berdasarkan data tersebut di atas, maka dapat dipahami bahwa ternyata keluarga nelayan dalam mewariskan pendidikan kepada anak-anaknya banyak bernafaskan mitos. Yang dimaksud mitos dalam tulisan ini adalah suatu keyakinan yang tidak berdasar pada ajaran agama yang benar, tapi diyakini sebagai sebuah kebenaran yang bersumber dari sang maha penguasa. Keyakinan keluarga nelayan terhadap halhal yang seperti ini sangat kental dan sangat sulit dihilangkan, karena faktor pemahaman mereka terhadap agama yang benar sangat kurang, hal ini berkorelaborasi dari latar belakang pendidikan mereka yang hanya tamatan SD saja. Dalam masalah keyakinan seperti ini tampak lehih teguh mengaplikasikannya dalam kehidupan seharihari.

Ketika anak mendampingi ayah di laut dalam mencari ikan, orang tua telah melakukan pendidikan kepada anaknya yang berlangsung secara alamiah. Artinya anak -anak nelayan dilibatkan secara langsung melakukan pelatihan-pelatihan secara langsung dengan cara anak melihat segala aktivitas ayah di laut.

Dalam kaitan di atas, maka salah seorang responden menuturkan bahwa:

Kalau saya pergi melaut pak, maka saya selalu melibatkan anak-anak saya untuk melihat segala aktivitas saya di laut. Dalam kondisi inilah, saya disela-disela kesibukan saya memberikan bimbingan kepada-anak-saya agar ia bisa terampil dalam menggunakan kapal. Atau setidak-tidaknya ia memiliki pemahaman sedikit tentang laut. ${ }^{65}$

Dengan demikian, berdasarkan uraian tersebut di atas, maka jelaslah, bahwa keluarga nelayan dalam mendidik anak-anak mereka di laut diperoleh secara alamiah saja. Anak hanya melihat secara langsung apa yang dilakuan bapaknya. Pada saat ayah

\footnotetext{
${ }^{63}$ Minggu Dg. Sikki, Wawancara pada tanggal 23 september 2017 di Dusu Soreang Desa Tamalate.

${ }^{64}$ Dg Nanga, Nelayan, Wawancara Pada Tanggal 5 September 2017 di Dusun Soreang Baru Desa Tamalate.

${ }^{65}$ Rahman Dg. Kulle, Nelayan. Wawancara pada Tanggal 25 september 2017 di Tamalate Kecamatan Galesong Utara Kabupaten Takalar. Proses pendidikan anak, yang berlangsung pada masyarakat nelayan berlngsung secara tidak terstruktur. Atau proses pendidikan yang berikan kepada para anak-anak nelayan berlangsung tanpa disengaja. Tapi walaupun begitu, pengetahuan yang diberikankepada anak bisa dikatan berlangsung dengan baik sesuai harapan orang tua. Harapan orang tua dalam mendidik anak di laut yang paling tinggi adalah agar anaknya bisa mewarisi pengetahuan ayahnya dalam melaut.
} 
sedang istirahat atau pada saat kondisi laut sedang bersahabat, maka anak mengambil alih pekerajaan ayahnya. Pekerjaan ini dilakukan berulang-ulang sampai akhirnya anak bisa melakukannya dengan baik.

Selanjuntya bagaimana pendidikan yang diterima anak-anak perempuan nelayan di rumah. Dalam kaitan ini, maka salah seorang informan menuturkan bahwa:

Saya mempunyai lima anak, tiga laki-laki dan dua perempuan. Anak-anak saya yang laki-laki ikut membantu bapaknya mencari ikan di laut. Anak saya yang perempuan membantu di rumah menyelesaikan tugas-tugas dalam rumah tangga. 66

Berdasarkan deskripsi tersebut di atas, maka peneliti dapat mendeskripsikan bahwa anak perempuan hanya fokus membantu ibunya di rumah untuk melakukan tugatugas keluarga. Terkait urusan melaut hanya dilakukan semata oleh bapaknya dan anaknya yang laki-laki. Mengapa demikian, karena secara fisik dia lebih kuat daripada istrinya.

Karena anak perempuan lebih banyak menghabiskan waktunya di rumah, maka ketika ia sudah beranjak dewasa misalnya pada usia 15 tahun atau ke atasnya, dan sudah ada yang mau melamarnya, maka keluarganya dengan cepat mengambil keputusan untuk segera dinikahkan saja.

Terkait pernyataan tersebut di atas, maka salah seorang informan menuturkan bahwa:

Ya, pak. semua anak saya yang perempuan menikah pada umur 16 tahun. Masing-masing tidak tamat sekolah Dasar (SD). Anak- anak di Desa Tamalate kalau tidak lagi sekolah, dan ada yang mau melamar, maka kami segera menerima lamarannaya. Apalagi saat ini, pengaruh teman-temannya (lingkungan) sangat dasyat, karena pada umumnnya semua anak-anak memiliki HP. ${ }^{67}$

Dengan demikian perilaku menikahkan masyakakat nelayan pada usia yang masih sangat muda sekali memang sudah sangat membudaya. Perkawinan seperti ini dilaksanakan secara turun temurun. Perilaku menikahkan pada usia dini sangat berkorelasi juga dari sikap orang tua dalam masalah pendidikan.

Relevan dengan data tersebut juga di atas, maka salah seorang istri nelayan menuturkan bahwa:

Anak saya yang perempuan dilamar waktu sekolah di kelas dua oleh tetangga.

Jadi, kami sekeluarga sangat merespon lamaran tersebut. Kalau anak saya sudah menikah berarti tanggung jawab saya sebagai orang tuanya sudah selesai. Bahkan, melalui pernikan anak saya, bisa membantu keluarga, apalagi saya sudah tua, pak. ${ }^{68}$

Dari deskripsi tersebut di atas, maka peneliti dapat mendeskripsikan bahwa pernikahan dini bagi masyarakat nelayan di Desa Tamalate, dan hal ini berlangsung dari generasi ke generasi. Perilaku menikahkan anak pada usia yang masih sangat muda atau masih di bawah umur ini sudah membudaya bagi komunitas nelayan pesisir.

\footnotetext{
${ }^{66}$ Tarring Dg. Caya, Wawancara pada tanggal 25 September, 2017 di Desa Tamalate.

${ }^{67}$ Bau Dg. Saga, Istri Nelayan. Wawancara, pada Tanggal 28 September 2017 di Desa Tamalate.

${ }^{68}$ Ramli Dg. Nai, Nelayan Wawancara Pada Tanngal 21 Okber 2017 di Desa Tamalate.
} 
Pendidikan anak dalam keluarga pesisir khusunya untuk pendidikan anak perempuan juga diberikan pengetahuan seputar tentang masalah atau hal -hal yang terkait kebutuhan kelancaran melaut. Yang mencakup: (1) Menambal jaring (2) Mengikat mata pancing (3) Mengurus kebutuhan rumah tangga keluarganya (4). Belajar memasak.

Sehubungan data tersebut di atas, maka salah seorang tokoh masyarakat menjelaskan bahwa :

Memang benar pak, bahwa anak-anak nelayan khususnya anak perempuan di desa saya Tamalate anak perempuan diajari oleh ibunya di rumah mengenai masalah menambal jaring yang robek atau rusak. Pekerjaan ini lebih banyak dilakukan oleh ibu dan anaknya di dalam rumah dan pada saat ayah nelayan pergi melaut. Oleh karena itulah pak, anak-anak perempuan pada umumnya memiliki keterampilan seperti yang diapresaisi di atas. ${ }^{69}$

Berdasarkan pernyataan tersebut di atas, maka peneliti dapat medeskripsikan bahwa anak-anak perempuan pesisir pada umumnnya diberi pengetahuan oleh keluarga mereka. Hal ini telah dilakukan sejak usia dini. Pengetahuan ini diberikan oleh keluarga hanya bersifat alamiah. Artinya anak-anak nelayan diajar tidak secara terprogram atau terstruktur, tapi cukup ibu mendemonstrasikan dan anak melihat secara langsung kemudian mempraktekannya.

\section{V.PENUTUP}

Berdasarkan paparan di atas, maka dapat disimpulkan bahwa perilaku keluarga nelayan dalam Pendidikan Anak di (informal) Desa Tamalate Kecamatan Galesong berdasarkan hasil temuan, bahwa: (a) Keluarga nelayan melakukan ritual-ritual appasili dengan melibatkan keluarga dan tetangga (b) Orang tua nelayan melakukan ritual/upacara kelahiran (appatompolo) yang bernuangsa keagamaan melaui upacara akikah.(c). Orang tua nelayan telah membiasakan anak-anak melaut pada usia dini 8-12 tahun (d) Pendidikan kegamaan yang diwarikan kepada anak dilakukan secara turun temurun (e) Keluarga nelayan melakukan upacara adat dan melakukan persembahan dengan cara memberikan sesajen kepada yang diyakini bisa memberi barakah pada saat turun melaut.

\footnotetext{
${ }^{69}$ Ana Dg Sannging, Istri Nelayan Wawancara, Tanggal 2 November di Desa Tamalate.
} 


\section{DAFTAR PUSTAKA}

Abdurrahman, Jalal, Pendidikan Ala Kanjeng Nabi Cet. I; Jogjakarta: Mitra Pustaka, 2003.

Boelaars, Yang, Kepribadian Indonesia Mderen: Suatu Penelitian Antropologi Budaya Jakarta: Gramedia, 1984.

Daradjat, Zakiah, Pendidikan Agama Dalam Keluarga, Bagi Anak Usia 6-12 Tahun dalam Pendidikan Agama dalam Keluarga ttp; Bandung: Remaja Rosda Karya, 1996.

Desmita, Psikologi Perkembangan, Cet. V, Bandung: Remaja Rosdakarya, 2009.

Harjanigrum, Agnes Tri, Peranan Orang Tua dan Praktisi dalam Membantu Tumbuh Kembang Anak Berbakat Melalui Pemahaman Teori dan Tren Pendidikan, Cet. I; Jakarta: Prenada Media Grup, 2007.

Imam Musbikin, Mendidik Anak Ala Shincan Cet. II; Yogyakarta: Mitra Pustaka, tth.

Jauziyah, Syamsu al-Din abi 'Abdillah Muhammad bin Qayyim al-, Tuhfat al-Maudūd bi Akhkām al-Maudūd(t.tp: MaktabahDāral-Bayān, t.th), h. 136.

Kessing, Roger M., Antropologi Budaya, Suatu Perspektif Kontemporer Jakarta: Erlangga, 1989. 
Kusnadi, Nelayan, Strategi Adaptasi dan Jaringan Sosial, Bandung: Humaniora Utama Perss, 2000.

Linrung, Tamsil, Potret Ketertinggalan Nelayan Kita t..tp: Hanana Press, 2007.

Masyhuri, Strategi Pengembangan Desa Nelayan Tertinggal, Organisasi Ekonomi Masyarakat Nelayan. Jakarta. Publitbang Ekonomi dan Pembangunan Lembaga Ilmu Pengetahuan Indonesia (PEP-LIPI), 1998

Mort, F.J. dkk, Psikologi Perkembangan ttp; Yogyakarta: Gajah Mada University Press, 1988.

Mujiran, Paulus, Pernik-Pernik Pendidikan Manifestasi dalam Keluarga, Sekolah dan Pentadaran Geder, Cet I, Yogyakarta; Pustaka Pelajar, 2002.

Nahlawi, Abd.al-Rahman al-, Usūl al-tarbiyah al-Islāmiyah wa Asalibihāa, Damsyik: Dār al-fikr, 1979.

Nelayan dan Kemiskinan, Studi Ekonomi Antropologi di Dua Desa Pantai, Jakarta: Rajawali Press.

Ondeng, Syaripuddin, Menyorot Lembaga Pendidikan Islam, Era Global Studi Kritis Terhadap Manajemen Madrasah di Era Informasi dan Komunikasi, Cet. I; Alauddin Pess, 2014.

Rahman, Jamal Abdul, Aifhfal al Muslimin Kaifa Rabbahum Nabiyy al-Amiin, Makkah al-Mukarramah: Dar al-Taybah al- Khadra, 2000

Shinya, Hiromi, The Miracle of Enzyme, Cet. X; Bandung: Mizan Media Utama, 2009.

Shochib, Mohammad, Pola Asuh Orang Tua dalam Membentuk Anak Mengembangkan Disiplin Diri, Cet. I; Jakarta: Rineka Cipta, 2000.

Tracy, Brian, Change Your Thingking, Change Your Life, Bebaskan Potensi Dashat Anda untuk Kesuksesan yang Tak Terbatas, Cet. III, Bandung, Mizan Pustaka, 2007.

Wahjoetomo, Perguruan Tinggi Pesantren Pendidikan Alternatif Masa Depan, Ttc. Jakarta: Gema Insani Press, 1997.

Wahyuni, Perilaku Beragama Studi Sosiologi terhadap Asimilasi Agama dan Budaya di Sulawesi Selatan, Cet. I: Tahun 2003.

Zaenuddin et.al, Seluk Beluk Pendidikan dari al-Ghazali Cet, I, Jakarta: Bumi Aksara, 2001.

\section{Sumber Wawancara}

Bauru Dg. Nyikko, Wawancara Pada Tanggal 25 September 2017 di Dusun Tamalate.

Dg. Bidolo, Buruh Nelayan, Wawancara Pada Tanggal 21 September 2017 Di Dusun Soreang Desa Tamalate.

Dg. Kanang, Istri nelayang. Wawancara, pada Tanggal 7 Maret, 2017 di Desa Tamalate.

Dg. Ngintang Baya, Istri nelayan Wawancara, di Desa Tamalate pada Tanggal 7 Maret, 2017

Dg. Kenna, istri nelayan, Wawancara pada tanggal 25 oktober 2017 di Desa Tamalate. 
Syamsuddin Dg. Tayang, Nelayan Wawancara pada Tanggal 25 September 2017 di Desa Tamalate.

Dg. Rate, Nelayan, Wawancara pada Tanggal 20 November 2017 di Dusun Soreang Desa Tamalate .

Dg. Sila, nelayan, wawancara pada tanggal 25 April di Desa Tamalate..

Dg. Mone, tokoh agama, Wawancara pada Tanggal 3 September 2017 di Dusun Bontotannga Deasa Tamalate

Istri nelayan, Wawancara pada Tanggal 25 April, 2017 di Desa Tamalate.

Bakri, anak nelayan Wawancara pada tanggal 25 April 2017 di Desa Tamalate

Risal, Anak nelayan. Wawancara pada tanggal 27 april 2017 di Desa Tamalate

Bauru Dg, Gau, Nelayan. Wawancara, di Desa Tamalate pada Tanggal 3 September 2017

Ahmad Dg. Boko, Wawancara di Desa Tamalate pada tanggal 3 September dan 25 Oktober 2017

Dg. Naba. Wawancara di Desa Tamalate pada Tanggal 28 Oktober 2017.

Dg. Cinnong, Istri buruh nelayang, Wawancara pada tanggal 26 Pebruari 2017 di Dusun Bontotannga Desa Tamalate.

Dg. Jai, Istri buruh nelayan, Wawancara, pada tanggal 27 Pebruari 2017 di Dusun Bontotannga Desa Tamalate

Dg. Darmawati, tokoh agama, Wawancara Pada tanggal 23 Pebruari 2017 di Desa Tamalate.

Tarawe Dg. Gassing, Nelayan. Wawancara pada Tanggal 29 Oktober 2017 di Dusun Bontotangnga Desa Tamalate.

Dg, Nai, Nelayan Wawancara Pada Tanggal 23 Oktober 2017 di Desa Tamalate.

Arman Dg. Tompo, Wawancara Pada Tanggal 25 September di Desa Tamalate.

Hatta Dg. Wawancara pada Tanggal 22 september 2017 di Desa Tamalate.

Sutte Dg. Gau, Wawancara pada Tanggal 22 Sepetember 2017 di Desa Tamalate.

Titto, Wawancara, pada Tanggal 23 September 2017 di Desa Tamalate

Dg. Nassa, Nelayan, Wawancara pada Tanggal 24 Oktober, 2017 di Desa Tamalate.

Ramli Dg. Nai, Nelayan Wawancara pada Tanngal 21 Okber 2017 di Desa Tamalate.

Suardi Dg. Ngewa, Nelayan Wawancara pada Tanngal 21 Oktober 2017 di Desa Tamalate.

Minggu Dg. Sikki, Wawancara pada tanggal 23 september 2017 di Dusu Soreang Desa Tamalate.

Dg Nanga, Nelayan, Wawancara Pada Tanggal 5 September 2017 di Dusun Soreang Baru Desa Tamalate.

Rahman Dg. Kulle, Nelayan. Wawancara pada Tanggal 25 september 2017 di Tamalate Kecamatan Galesong Utara Kabupaten Takalar.

Tarring Dg. Caya, Wawancara pada tanggal 25 September, 2017 di Desa Tamalate.

Bau Dg. Saga, Istri Nelayan. Wawancara, pada Tanggal 28 September 2017 di Desa Tamalate.

Ramli Dg. Nai, Nelayan Wawancara Pada Tanngal 21 Okber 2017 di Desa Tamalate. Ana Dg Sannging, Istri Nelayan Wawancara, Tanggal 2 November di Desa Tamalate. 